\title{
Dignity-conserving care for persons with palliative care needs - identifying outcomes studied in research: An integrative review
}

\section{Review Article}

Cite this article: Söderman A, Östlund U, Werkander Harstäde C, Blomberg K (2020). Dignityconserving care for persons with palliative care needs - identifying outcomes studied in research: An integrative review. Palliative and Supportive Care 18, 722-740. https://doi.org/10.1017/

S1478951520000139

\section{Received: 20 May 2019}

Revised: 15 January 2020

Accepted: 27 January 2020

\section{Keywords:}

Dignity-conserving care; Human dignity;

Outcome assessment; Palliative care; Review

\section{Author for correspondence: Annika}

Söderman, Faculty of Medicine and Health,

School of Health Sciences, Örebro University,

Örebro 701 82, Sweden. E-mail: annika.

soderman@oru.se
Annika Söderman, R.N., H.C.N., PH.D. STUDENT ${ }^{1}$ (D), Ulrika Östlund, R.N., O.C.N., PH.D., ASSOC. PROF. ${ }^{2}$, Carina Werkander Harstäde, R.N., PH.D., ASSOC. PROF. ${ }^{3}$ and Karin Blomberg, R.N., PH.D., PROFESSOR ${ }^{1}$

${ }^{1}$ Faculty of Medicine and Health, School of Health Sciences, Örebro University, Örebro, Sweden; ${ }^{2}$ Centre for Research and Development, Uppsala University/Region Gävleborg, Gävle, Sweden and ${ }^{3}$ Centre for Collaborative Palliative Care, Faculty of Health and Life Sciences, Department of Health and Caring Sciences, Linnaeus University, Växjö, Sweden

\begin{abstract}
Objectives. With people living longer, palliative care may be required for lengthier periods of time. This puts demands on healthcare organizations to provide optimal palliative care. Maintaining dignity is central for any person's health and quality of life, but especially for a person with palliative care needs. Dignity-conserving care needs to be evaluated to increase knowledge about outcomes and how to assess these. The purpose of this integrative review was to identify outcomes studied within dignity-conserving care and how these have been operationalized.

Methods. An integrative review was conducted in 26 quantitative or mixed-method studies and study protocols. Thematic synthesis with an abductive approach was used for analysis.

Results. Seven themes of studied outcomes were identified, as well as four cluster themes: themes related to Illness-Related Concerns, themes related to the Dignity-Conserving Repertoire, themes related to the Social Dignity Inventory, and themes regarding Overarching Dignity Issues. Most outcomes studied dealt with Illness-Related Concerns within the themes of "Performance, symptoms and emotional concerns" and "End-of-life and existential aspects". Themes linked to the Social Dignity Inventory had the lowest number of outcomes studied. Outcomes regarding overarching dignity issues such as "Dignity-related distress" and "Quality of life" were common. However, the results lacked concrete communication outcomes.

Significance of results. The results will underpin future research in which dignity-conserving care is implemented and evaluated, and contribute to the provision of evidence-based palliative care. A greater focus on outcomes within cluster themes related to the Dignity-Conserving Repertoire and the Social Dignity Inventory is needed, as is more focus on communication outcomes.
\end{abstract}

\section{Introduction}

A primary goal in palliative care is to ensure a high quality of life for persons with palliative care needs, which involves taking psychosocial, spiritual, and physical dimensions into account (World Health Organization/Worldwide Palliative Care Alliance, 2014). The World Health Organization (WHO) in 2018 reported that, globally, 40 million people are terminally ill, and millions of others not imminently dying need palliative care. However, $86 \%$ of those in need of palliative care do not receive the needed care, and access is unequal on the basis of age, diagnosis, and home location (Lindskog et al., 2015; World Health Organization/Worldwide Palliative Care Alliance, 2014; World Health Organization, 2018). Still, within palliative care, dignity-conserving care must be provided in various contexts for all persons who need it (Chochinov, 2007).

Core values of dignity-conserving care are dignity, kindness, and respect, and remembering to "care for" the person. A healthcare professional's attitude, behavior, compassion, and use of dialog are important components of dignity-conserving care (Chochinov, 2007). Dignity is central for persons experiencing difficulties with an illness (Brennan, 2017). It has been described that in healthcare, persons have dignity when they are able to live in agreement with their principles and values (Barclay, 2016). Persons who have problems with a failing body can be vulnerable and can lose control over their body and their immediate environment, which naturally impacts their ability to uphold standards and values (Barclay, 2016), leading to loss of dignity (Barclay, 2016; Kennedy, 2016). Loss of dignity is a reality for many older persons and persons who are seriously ill (Gallagher et al., 2008; van Gennip et al., 2015), affecting between $4 \%$ and $11 \%$ of older and ill people in non-cancer populations (Chochinov et al., 2016), and reported as a significant problem for patients with cancer (Hack et al., 2004). 
Table 1. Search strategy

\begin{tabular}{|c|c|c|}
\hline $\begin{array}{l}\text { Main } \\
\text { search }\end{array}$ & Additional key words & Limitations \\
\hline \multicolumn{3}{|l|}{ Cinahl } \\
\hline $\begin{array}{l}\text { Human Dignity }{ }^{1} \text { OR } \\
\text { Individuality }^{1} \text { OR Digni } \\
\text { OR Personhood }\end{array}$ & 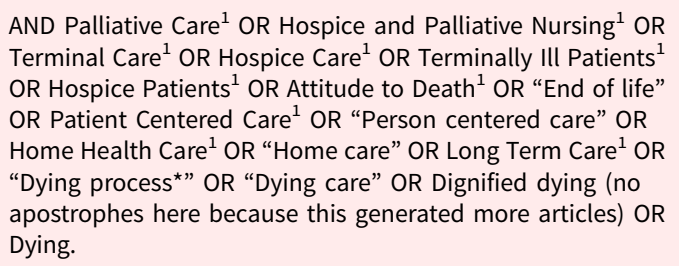 & $\begin{array}{l}\text { English language; peer-reviewed; date 1997/01/01-2017/12/ } \\
\text { 31; all adult. }\end{array}$ \\
\hline \multicolumn{3}{|l|}{ Medline } \\
\hline $\begin{array}{l}\text { "Human dignity" OR } \\
\text { Individuality }{ }^{2} \text { OR Digni* } \\
\text { OR Personhood² }\end{array}$ & $\begin{array}{l}\text { AND Palliative Care }{ }^{2} \text { OR Hospice and Palliative Care Nursing } \\
\text { OR Terminal Care }{ }^{2} \text { OR Hospice Care }{ }^{2} \text { OR Terminally Ill }{ }^{2} \text { OR } \\
\text { "Hospice patient"” OR Attitude to Death }{ }^{2} \text { OR "End of life" } \\
\text { OR Patient Centered Care }{ }^{2} \text { OR "Person centered care" OR } \\
\text { Home Health Nursing }{ }^{2} \text { OR "Home health care" OR "Home } \\
\text { care" OR Long-Term Care }{ }^{2} \text { OR "Dying process" OR "Dying } \\
\text { care" OR Dignified dying OR Dying. }\end{array}$ & English language; date 1997/01/01-2017/12/31; all adult. \\
\hline \multicolumn{3}{|l|}{ PsycINFO } \\
\hline $\begin{array}{l}\text { "Human dignity" OR } \\
\text { Dignity }{ }^{3} \text { OR Digni* OR } \\
\text { Individuality }{ }^{3} \text { OR } \\
\text { Personhood* }\end{array}$ & 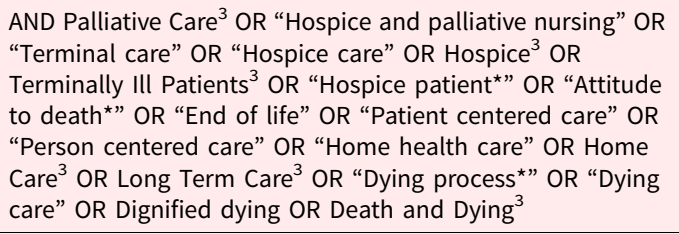 & $\begin{array}{l}\text { English language; peer-reviewed; date 1997/01/01-2017/12/ } \\
\text { 31; adulthood (18yrs \& older) }\end{array}$ \\
\hline \multicolumn{3}{|l|}{ Web of Science } \\
\hline $\begin{array}{l}\text { "Human dignity" OR } \\
\text { Individuality OR Digni* } \\
\text { OR Personhood* }\end{array}$ & $\begin{array}{l}\text { AND "Palliative care" OR "Hospice and Palliative nursing" } \\
\text { OR "Terminal care" OR "Hospice care" OR "Terminally ill } \\
\text { patient" OR "Hospice patient" OR "Attitude to death" OR } \\
\text { "End of life" OR "Patient centered care" OR "Person } \\
\text { centered care" OR "Home health care" OR "Home care" OR } \\
\text { "Long term care" OR "Dying process" OR "Dying care" OR } \\
\text { "Dignified dying" OR Dying }\end{array}$ & $\begin{array}{l}\text { English language; publication years } 1997-2017 \text {; document } \\
\text { types: articles, reviews, proceedings paper. Refined search } \\
\text { with: Adulthood OR "All adult*” OR Elderly OR “Old* people" } \\
\text { OR "Old* person" }\end{array}$ \\
\hline
\end{tabular}

${ }^{1}$ Subject heading; ${ }^{2}$ MeSH term; ${ }^{3}$ Thesaurus. The use of caps ("”) keep words together in a keyword search.

${ }^{*}$ The search-term was used with truncation.

Further, dignity has been recognized as a human right (Hemati et al., 2016; Johnston et al., 2017a).

Interventions to conserve dignity can contribute to improved palliative care (Johnston et al., 2017b) but their value to a person's health, and how they can be evaluated in a proper manner must be further explored to find out the most optimal setup of an intervention and how it should best be implemented to maintain a person's dignity. Previous studies (Johnston et al., 2017a, 2017b; Mcllfatrick et al., 2017) raise the importance of interventions aiming to conserve severely ill persons' dignity and of evaluating their effectiveness before implementing them in care (Lendon et al., 2015). In the future, healthcare will be based not so much on activities, but rather on outcomes (Department of Health, 2010). Outcome assessment has been defined as "research aimed at assessing the quality and effectiveness of health care as measured by the attainment of a specified end result or outcome ..." (Jefford et al., 2003, p. 110). Outcome research is important to provide information that inform patient decisions, guide healthcare professionals, and inform health policy decisions (Jefford et al., 2003). Thus, research on this topic and consideration of relevant outcomes are central to implement new interventions. This will enable healthcare providers to assess the strength of evidence (Bland, 2015). Today, outcomes targeting dignity-conserving care need to be further explored and clarified. Previous reviews have focused on: dignity therapy (DT) and its effects (Fitchett et al., 2015; Donato et al., 2016; Martínez et al., 2017; Xiao et al., 2019), overviews of psychological/psychosocial interventions (Hulbert-Williams et al., 2018; Teo et al., 2018; von Blanckenburg and Leppin, 2018; Warth et al., 2019), evidence of existential interventions (Bauerei $\beta$ et al., 2018), interventions with biographical approaches (Hesse et al., 2019), personal narrative interventions (Roikjær et al., 2019), and death anxiety interventions (Grossman et al., 2018). These reviews did not have a clear focus on outcomes studied within dignity-conserving care, and without such overviews, it could be difficult to introduce this type of care within palliative care.

To the best of our knowledge, no overview has been conducted of research concerning outcomes studied after different interventions for dignity-conserving care. Hence, this integrative review aims to identify outcomes studied after different interventions in dignity-conserving care and to find out how these have been operationalized through various instruments.

\section{Method}

\section{Design}

This study has an integrative review design (Whittemore and Knafl, 2005) to allow for the inclusion of primary studies with a 
combination of diverse methodologies such as quantitative studies, mixed-methods, and study protocols.

\section{Search strategy}

Searches were undertaken in four databases: CINAHL, MEDLINE, PsycINFO, and Web of Science, and limited to the time period 1997-2019. A broad and inclusive approach was used in preliminary searches to scope out the field. Indexing terms were established, as well as key words for free-text searching. Free-text key words were only used as a complement to indexing terms. In Web of Science, only free-text key words were available. The searches were started in CINAHL, where terms related to dignity (e.g. synonyms such as "personhood") and terms related to palliative care (e.g. synonyms such as "end of life care") were combined with Boolean operators "OR" and "AND." Moreover, the searches were limited to English language, peer-review, and "all adult" (aged $\geq 18$ years) studies. Where needed, the combination of search terms in CINAHL was modified for MEDLINE, PsycINFO, and Web of Science. The search strategy (Table 1) was discussed with and validated by a librarian. The database searches identified 1,619 articles. In addition, a manual search was conducted (Whittemore and Knafl, 2005) by networking within the research group and searching through reference lists of the already included articles, generating a further 59 articles (giving a total of 1,678 articles).

\section{Selection of articles}

Inclusion and exclusion criteria (Table 2) were applied. The inclusion criterion "match the aim of the review" was applied to all titles by researcher A.S., and 758 articles were excluded (see Figure 1 and Table 3 for the selection process and search results). All inclusion and exclusion criteria were used on the titles and abstracts of the remaining articles by two researchers (A.S. and K.B.) separately before they compared their independent selections, discussed disparities, and reached agreement. To validate the selection process, researchers U.Ö. and C.W.H. reviewed a selection of preliminarily included or excluded articles. This process led to discussions among all the researchers about the selection criteria until consensus was reached. This process excluded 784 articles. Full-text papers were retrieved, read in full, and reviewed by researchers A.S. and K.B., leading to exclusion of 61 articles (75 articles remaining). After a validating discussion among all the researchers, 40 articles remained. There were 16 doublets, so the final selection included 24 articles. An updated search was done in February 2019, which added two more articles to the result $(n=26)$ (Tables 4 and 5).

\section{Data analysis}

Based on Whittemore and Knafl's (2005) recommendation, an analysis for mixed or qualitative method research, thematic synthesis (Lucas et al., 2007) was chosen to analyze the text of identified articles and facilitate the structuring of data. Further, an abductive approach (Alvesson, 2017) was used, which assumes empirical facts but does not reject theoretical beliefs in discovering patterns that generate a deeper understanding about outcomes. Themes of outcomes were created inductively, while cluster themes were created deductively. To identify themes, researchers A.S. and U.Ö. first read and reread the articles, and focused on manifest data regarding the aim. A.S. and U.Ö. analyzed five articles separately and then discussed them together
Table 2. Inclusion and exclusion criteria for articles

Inclusion criteria:

- Match the aim of the review.

- Focus on palliative care or synonyms for this term (e.g. end-of-life).

- Evaluate interventions for dignified care/dignity-conserving care.

- Describe quantitative outcomes of the care provided or planned care.

- Adults $\geq 18$ years old in home care or nursing homes, alternatively within palliative care units and palliative care teams (which may be in or out of hospitals).

- Are based on the perspective of adults, or the perspectives of relatives or healthcare professionals.

Exclusion criteria:

- Are qualitative studies, reviews or case studies.

- Are quantitative studies only including surveys, feedback questionnaires and single-item scales.

- Focus on instruments that measure dignity, but do not include an intervention.

- Focus on a dignified death in relation to euthanasia.

- Do not allow extraction of results from adults.

- Exclusively include persons with dementia or with severe cognitive disorders.

to establish and validate what should be extracted from the articles. Further, all researchers were involved in the analysis of the articles. Data were inductively collated based on questions derived from the study aim: "What outcomes were studied?" and "How were outcomes operationalized?" This process resulted in seven themes. Further, the three main categories of Chochinov's dignity model (Illness-Related Concerns, the Dignity-Conserving Repertoire, and the Social Dignity Inventory; Figure 2; Chochinov, 2002) were used as a grid to deductively gather results into cluster themes. Some themes could not be clustered to the three main categories, which generated a fourth cluster theme: "Themes regarding Overarching Dignity Issues" (Table 7). For trustworthiness, themes and cluster themes were validated through discussions within the research group. In the last step, an agreed synthesis was produced, reporting main results.

\section{Results}

The final study set comprised 26 articles (for study characteristics, see Tables 4 and 5; for included interventions, see Table 6). The findings are presented within four cluster themes and seven themes (Table 7 for overview of outcomes studied in research, see supplementary material). The cluster theme including the most outcomes was "Themes related to Illness-Related Concerns" $(n=19)$, while the "Themes related to the Social Dignity Inventory" covered the fewest of the studied outcomes $(n=3)$. Most of the reported outcomes have been studied, but outcomes reported in study protocols are proposed to be studied. To increase the readability of results, study numbers [e.g. Study 1 (S1)] are used (below and in Tables 4 and 5) instead of references for each included article.

\section{Themes related to Illness-Related Concerns}

\section{Performance, symptoms and emotional concerns}

This theme included studied outcomes related to performance, symptoms, and emotional concerns. The outcome "Performance status" was studied after the implementation of DT and operationalized using the Palliative Performance Scale ${ }^{\mathrm{S} 5}$ or the Palliative Performance Scale version 2 (PPSv2) ${ }^{\text {S10 }}$. Further, post-DT, "Symptoms" as an outcome were studied using the Edmonton 


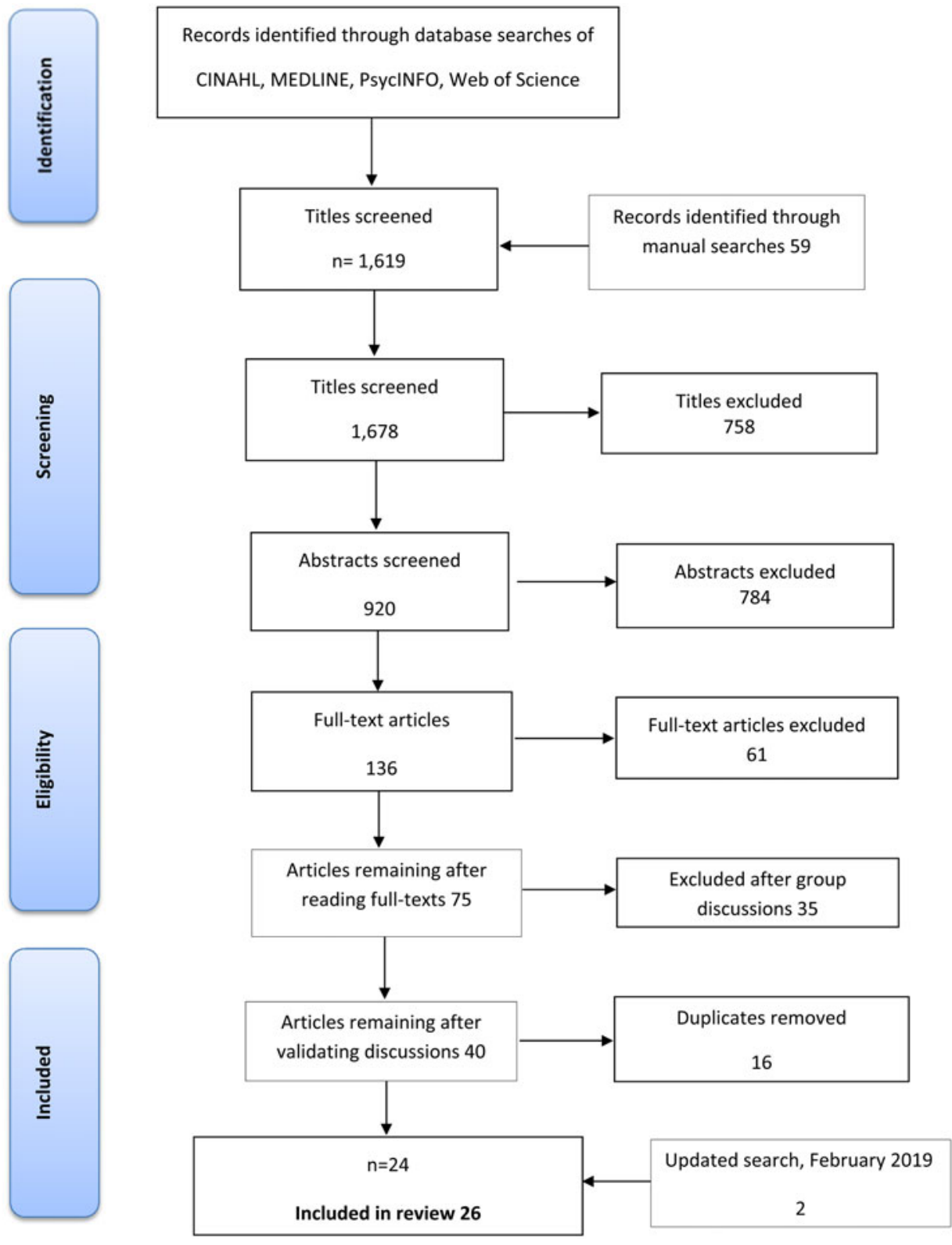

Fig. 1. Flow chart of the literature search; PRISMA flow diagram (Moher et al., 2009)

Symptom Assessment System (ESAS) ${ }^{\mathrm{S}, \mathrm{S} 19}$ including both emotional symptoms and physical symptoms, while "Symptoms and concerns" were studied using the Structured Interview for Symptoms and Concerns (SISC) ${ }^{\mathrm{S} 5,}$ S10. Additionally, by using heart rate variability ${ }^{\mathrm{S} 3}$, a biomarker reflecting cardiovascular regulation, investigators planned to study "Psychophysiological wellbeing" as an outcome following the Family Dignity Intervention (FDI), while "Distress" was studied post-DT and operationalized through the Distress Thermometer, a 0-10 Likert scale that has been validated in cancer populations ${ }^{\mathrm{S} 19}$. Moreover, investigators planned to study emotional concerns after DT implementation through the outcome "Affective states," operationalized through the Positive and Negative Affect Schedule (PANAS), ${ }^{\mathrm{S} 15}$ and "Psychological wellbeing," through the 20 -item Life Closure Scale $(\mathrm{LCS})^{\mathrm{S} 15}$. The outcome "Psychological distress" was studied post-DT ${ }^{\mathrm{S} 5}, \mathrm{~S} 6, \mathrm{~S} 7, \mathrm{~S} 9$, post-FDI ${ }^{\mathrm{S} 23}$, and post-implementation of the Dignity-Conserving End-of-Life Care Program ${ }^{\mathrm{S} 22}$. It was proposed to be operationalized through the Geriatric Depression Scale ${ }^{\mathrm{S} 6}$, the
Distress Thermometer ${ }^{\mathrm{S} 7}$, or the Patient Health Questionnaire- $9^{\mathrm{S} 23}$ or was operationalized through the Hospital Anxiety and Depression Scale (HADS) ${ }^{\mathrm{S} 9}$, the SISC ${ }^{\mathrm{S}}$, or the McGill Quality of Life Questionnaire ${ }^{\text {S22 }}$. Moreover, "Depression" was studied after DT and was further proposed to be operationalized using the $\mathrm{HADS}^{\mathrm{S} 5, \mathrm{~S} 9}$, S10, S12, S13, S15, S17, the 15-item Geriatric Depression $\mathrm{Scale}^{\mathrm{S} 8}$, the second edition of the 21-item Beck Depression Inventory ${ }^{\mathrm{S} 11}$, or the Zung Self-Rating Depression Scale ${ }^{\mathrm{S} 16}$. Another outcome within this theme, proposed or studied after DT, was "Anxiety" which was operationalized through the

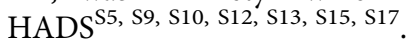

\section{End-of-life and existential aspects}

This theme included studied outcomes relating to end-of-life and existential aspects. "End-of-life psychological experiences" as an outcome of DT were studied using demoralization syndrome (DS) criteria, the Desire for Death scale, and the Patient Dignity Inventory $(\mathrm{PDI})^{\mathrm{S} 14}$. Further, "Palliative care needs" as 
Table 3. Search outcomes from diverse databases and sources

\begin{tabular}{|c|c|c|c|c|c|c|}
\hline Source & Total & $\begin{array}{l}\text { Excluded on } \\
\text { title }\end{array}$ & $\begin{array}{l}\text { Excluded on } \\
\text { abstract }\end{array}$ & $\begin{array}{l}\text { Excluded on } \\
\text { full text }\end{array}$ & Doublets & $\begin{array}{c}\text { Included after discussions (number of } \\
\text { included articles after excluding } \\
\text { doublets) }\end{array}$ \\
\hline Cinahl & 530 & 146 & 343 & 19 & & $13(13)$ \\
\hline Medline & 525 & 301 & 189 & 13 & 9 & $13(4)$ \\
\hline PsycINFO & 418 & 256 & 136 & 9 & 6 & $6(0)$ \\
\hline Web of Science & 146 & 55 & 80 & 6 & 1 & $2(1)$ \\
\hline $\begin{array}{l}\text { Networking/searching } \\
\text { through reference lists }\end{array}$ & 59 & 0 & 36 & 14 & 0 & $6(6)$ \\
\hline $\begin{array}{l}\text { Updated search, } \\
\text { February } 2019\end{array}$ & & & & & & $2(2)$ \\
\hline
\end{tabular}

an outcome was proposed or studied through the Palliative care Outcome Scale (POS) ${ }^{\mathrm{S} 7}$, S9 , and "Goals of care and treatment preferences in end of life" were studied using the Hypothetical Advanced Care Planning Scenario (H-CAP-S $)^{\mathrm{S} 19}$, both post-DT. Additionally, existential outcomes were studied after DT: "Sense of life closure" was proposed through the use of the $\mathrm{LCS}^{\mathrm{S} 15}$ or studied through the Herth Hope Index $(\mathrm{HHI})^{\mathrm{S} 9}$. "Existential wellbeing" was studied through the Functional Assessment of Chronic Illness Therapy - the 12-item Spiritual Well-Being Scale (FACIT-sp.) $)^{\mathrm{S} 3}$, and "Existential distress" was studied using the SISC $^{\mathrm{S} 5}$, and in another study on five individual items (anxiety, sense of suffering, desire for death, lack of wellbeing, and perceived loss of dignity) ${ }^{\mathrm{S} 11}$ each one scored on a range from 0 to 6. "Purposelessness" as an outcome was further studied and operationalized through the Purposelessness, Understimulation and Boredom (PUB) scale ${ }^{\mathrm{S} 16}$, while outcomes such as "Will to live" and "Desire for death" were studied and operationalized with the will-to-live visual analog scale included in the ESAS ${ }^{\mathrm{S}}$, S5 and the Desire for Death Rating Scale (DDRS) ${ }^{\text {S14 }}$, all after DT.

\section{Themes related to the Dignity-Conserving Repertoire}

\section{Essential life values}

This theme included outcomes relating to hope, meaning, and spirituality. The outcome "Hope" was studied or proposed to be through the HHI after $\mathrm{DT}^{\mathrm{S} 2 \text {, }}$ S15, while "Hopefulness" was proposed or studied through the same instrument (HHI) after $\mathrm{DT}^{\mathrm{S1}}, \mathrm{S6}, \mathrm{S7}, \mathrm{S8}, \mathrm{S9}$ or the $\mathrm{FDI}^{\mathrm{S} 23}$. Another outcome was "Meaning in life," which investigators proposed to study through the use of the Life Evaluation Questionnaire, the 5-item Appreciation of Life subscale, the 8-item Contentment subscale, and the 8-item Social Integration subscale ${ }^{\mathrm{S} 15}$ (after DT), or through a modified Cancer Coherence scale ${ }^{\mathrm{S} 23}$ (after FDI). Moreover, the outcome "Spirituality" was studied using the GES (Grupo de Espiritualidad de la Sociedad Española de Cuidados Paliativos) questionnaire ${ }^{\mathrm{S} 17}$ or the Dignity Impact Scale (DIS) ${ }^{\text {S18 }}$ post-DT, while "Spiritual well-

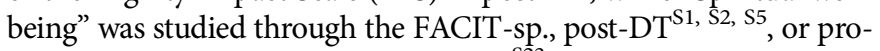
posed to be studied that way post-FDI ${ }^{\mathrm{S} 23}$.

\section{Aspects of personal strength and coping}

Some of the studied outcomes could be related to personal strength and coping. The outcome "Self-efficacy" was proposed as a mediating or moderating factor through the General Self-Efficacy (GSE) scale ${ }^{\mathrm{S} 15}$, while "Resilience" was proposed to be studied through the Connor-Davidson Resilience Scale
(CD-RISC) $^{\mathrm{S} 15}$ or was studied with the Brief Resilient Coping Scale $(B R C S)^{S 17}$ (all after DT). In addition, the outcome "Empowerment" was studied through the Empowerment Scale (after the intervention targeting fundamental values) ${ }^{\mathrm{S} 26}$, and the outcome "Post-traumatic growth" was proposed by using the Post-traumatic Growth Inventory (PTGI) after administering the Revie $\oplus$ intervention $^{\text {S21 }}$. Investigators proposed to use "Psychological adaptation" as an outcome with the $\mathrm{LCS}^{\mathrm{S} 15}$, while "Death acceptance" was studied through the Terminal Illness Acknowledgement (TIA) questionnaire ${ }^{\mathrm{S} 19}$, both after DT.

\section{Themes related to the Social Dignity Inventory}

\section{Aspects of care tenor and social support}

This theme included aspects of care tenor and social support. The outcome "Person-centred care climate" was studied after the implementation of the Patient Dignity Question (PDQ) tool ${ }^{\mathrm{S} 24}$, ${ }_{\text {S25 }}$ and an intervention targeting fundamental values ${ }^{\mathrm{S} 26}$, and further operationalized through the Person-centered Climate Questionnaire-Patient (PCQ-P) including three subscales measuring: a climate of safety, a climate of everydayness, and a climate of hospitality. Moreover, the outcome "Empathy" was studied and operationalized through the Consultation And Relational Empathy (CARE) measure ${ }^{\mathrm{S} 25}$ or the Empathy questionnaire ${ }^{\mathrm{S} 20}$ for healthcare professionals after administering the PDQ. "Social support" was another outcome studied post-DT; it was operationalized through the Duke-UNC-11 Functional Social Support Questionnaire ${ }^{\text {S17 }}$, focusing on confidential support (support for communicating intimate feelings) and affective support (support for positive empathy). In one study, investigators proposed a modified version of the Inventory of Social Support ${ }^{\mathrm{S} 23}$ to study the same outcome after FDI.

\section{Themes regarding Overarching Dignity Issues}

Some themes were classifiable under more than one of the three main categories in Chochinov's dignity model (Chochinov, 2002); for this reason, we considered them to reflect more broad or overarching dignity-related concerns.

\section{Aspects of dignity and gratitude}

The theme "Aspects of dignity and gratitude" was seen as a broad theme featuring in Illness-Related Concerns, the DignityConserving Repertoire, and the Social Dignity Inventory. 
Table 4. Articles ( $n=19)$ focusing on the DT intervention

\begin{tabular}{|c|c|c|c|c|c|}
\hline Study & Aim & $\begin{array}{l}\text { Design } \\
\text { Sample } \\
\text { Setting }\end{array}$ & $\begin{array}{l}\text { Intervention (I) } \\
\text { Control (C) } \\
\text { Data collection (D) }\end{array}$ & Key findings & Perspective \\
\hline $\begin{array}{l}\text { Aoun et al. (2015) } \\
\text { Study } 1 \text { (S1) }\end{array}$ & $\begin{array}{l}\text { To assess the acceptability, } \\
\text { feasibility, and effectiveness of DT } \\
\text { to reduce distress in people with } \\
\text { motor neuron disease (MND) and } \\
\text { their family caregivers. }\end{array}$ & $\begin{array}{l}\text { A feasibility study with a quantitative } \\
\text { approach. } \\
\text { Participants - members of the } \\
\text { support organization, the MND } \\
\text { Association of Western Australia. } \\
\text { Patients ( } n=27 \text { ) from home-based } \\
\text { care, family caregivers ( } n=18 \text { ), in } \\
\text { Australia. }\end{array}$ & $\begin{array}{l}\text { I: DT. } \\
\text { C: no control group. } \\
\text { D: repeated-measures pre- and } \\
\text { post-intervention. }\end{array}$ & $\begin{array}{l}\text { - DT was well accepted. } \\
\text { - No significant differences were seen in } \\
\text { outcomes, but patients described high } \\
\text { satisfaction with and endorsement of } \\
\text { DT. Family caregivers agreed that DT } \\
\text { document will continue to be a source } \\
\text { of comfort. }\end{array}$ & $\begin{array}{l}\text { - Persons } \\
\text { with } \\
\text { palliative } \\
\text { care needs } \\
\text { - Relatives } \\
\text { (family } \\
\text { caregivers) }\end{array}$ \\
\hline $\begin{array}{l}\text { Bentley et al. (2014) } \\
\text { (S2) }\end{array}$ & $\begin{array}{l}\text { To assess the feasibility, } \\
\text { acceptability, and potential } \\
\text { effectiveness of DT for people with } \\
\text { MND. }\end{array}$ & $\begin{array}{l}\text { A cross-sectional feasibility study } \\
\text { using a one-group pre-test/post-test } \\
\text { design. } \\
\text { Participants were people diagnosed } \\
\text { with MND ( } n=29) \text { living at home or } \\
\text { in an aged care facility in Australia. }\end{array}$ & $\begin{array}{l}\text { I: DT. } \\
\text { C: no control group. } \\
\text { D: self-report questionnaires. }\end{array}$ & $\begin{array}{l}\text { - No significant pre-test/post-test } \\
\text { differences for hopefulness, spirituality } \\
\text { or dignity at the group level, but } \\
\text { changes in hopefulness at the } \\
\text { individual level. } \\
\text { - DT was greatly acceptable to people } \\
\text { with MND and is feasible if therapists } \\
\text { overcome time and communication } \\
\text { difficulties. Benefits included better } \\
\text { family relationships, improved sense of } \\
\text { self and greater acceptance. }\end{array}$ & $\begin{array}{l}\text { - Persons } \\
\text { with } \\
\text { palliative } \\
\text { care needs }\end{array}$ \\
\hline $\begin{array}{l}\text { Bernat et al. (2015) } \\
\text { (S3) }\end{array}$ & $\begin{array}{l}\text { To assess the feasibility and } \\
\text { acceptability of a web-enhanced } \\
\text { and abbreviated DT intervention. }\end{array}$ & $\begin{array}{l}\text { Feasibility study with before and } \\
\text { after assessments. } \\
\text { Adults with terminal cancer }(n=16) \text {. } \\
\text { Outpatient oncology clinic, } \\
\text { academic medical center, USA. }\end{array}$ & $\begin{array}{l}\text { I: an abbreviated DT } \\
\text { intervention using a } \\
\text { legacy-building web portal. } \\
\text { C: no control group. } \\
\text { D: baseline and } \\
\text { post-intervention surveys. }\end{array}$ & $\begin{array}{l}\text { - Acceptability of the intervention on a } \\
0-10 \text { Likert scale was } M=8.82, \mathrm{SD}= \\
1.08 \text {; acceptability of the final legacy } \\
\text { project was } M=8.55, \mathrm{SD}=1.13 \text {. Of } \\
\text { patients using the web portal, } 80 \% \\
\text { were dissatisfied. } \\
\text { - Meaning in life and dignity-related } \\
\text { distress did not significantly differ from } \\
\text { baseline. }\end{array}$ & $\begin{array}{l}\text { - Persons } \\
\text { with } \\
\text { palliative } \\
\text { care needs }\end{array}$ \\
\hline $\begin{array}{l}\text { Chochinov et al. } \\
\text { (2005) } \\
\text { (S4) }\end{array}$ & $\begin{array}{l}\text { To establish the feasibility of DT } \\
\text { and determine its impact on } \\
\text { various measures of psychosocial } \\
\text { and existential distress. }\end{array}$ & $\begin{array}{l}\text { A feasibility study with qualitative } \\
\text { and quantitative methods. } \\
\text { Terminally ill patients }(n=100) \text {. } \\
\text { Inpatients and those receiving } \\
\text { home-based palliative care services } \\
\text { in Canada and Australia. }\end{array}$ & $\begin{array}{l}\text { I: DT. } \\
\text { C: no control group. } \\
\text { D: pre- and post-intervention } \\
\text { measures and a } \\
\text { post-intervention satisfaction } \\
\text { survey. }\end{array}$ & $\begin{array}{l}\text { - Patients who felt satisfied or highly } \\
\text { satisfied with DT were } 91 \% \text {. } \\
\text { - Suffering/self-reports of depressed } \\
\text { mood improved (significant), dignity } \\
\text { improved (approached significance), } \\
\text { hopelessness, desire for death, anxiety, } \\
\text { will to live, and suicide showed no } \\
\text { significant changes suggesting } \\
\text { improvement. Wellbeing and quality of } \\
\text { life diminished a little (non-significant). }\end{array}$ & $\begin{array}{l}\text { - Persons } \\
\text { with } \\
\text { palliative } \\
\text { care needs }\end{array}$ \\
\hline
\end{tabular}




\begin{tabular}{|c|c|c|c|c|c|}
\hline Study & Aim & $\begin{array}{l}\text { Design } \\
\text { Sample } \\
\text { Setting }\end{array}$ & $\begin{array}{l}\text { Intervention (I) } \\
\text { Control (C) } \\
\text { Data collection (D) }\end{array}$ & Key findings & Perspective \\
\hline $\begin{array}{l}\text { Chochinov et al. } \\
\text { (2011) } \\
\text { (S5) }\end{array}$ & $\begin{array}{l}\text { To investigate whether DT would } \\
\text { be better than SPC and } \\
\text { patient-centred care in terms of } \\
\text { reducing psychological, existential, } \\
\text { and spiritual distress in patients } \\
\text { who are terminally ill. }\end{array}$ & $\begin{array}{l}\text { A randomized controlled study with } \\
\text { a before and after design. } \\
\text { Patients with a terminal prognosis } \\
\text { ( } n=441) \text {. } \\
\text { Palliative care in a hospital or } \\
\text { community setting (hospice or } \\
\text { home) in Canada, the USA, Australia. }\end{array}$ & $\begin{array}{l}\text { I: DT }(n=165) \text {. } \\
\text { C: Client-Centred Care (CCC) } \\
(n=136) \text { or SPC }(n=140) \text {. } \\
\text { D: before and after } \\
\text { measurements and } \\
\text { self-reported end-of-life survey. }\end{array}$ & $\begin{array}{l}\text { - Significantly more patients receiving DT } \\
\text { reported satisfaction than in the SPC } \\
\text { group. Before and after measurements } \\
\text { showed no significant differences } \\
\text { between groups. Patients given DT were } \\
\text { significantly more likely to report } \\
\text { treatment as helpful to them, and as } \\
\text { improving their quality of life and sense } \\
\text { of dignity, as well as significantly more } \\
\text { likely to report that the study treatment } \\
\text { changed how their family saw and } \\
\text { appreciated them. DT was significantly } \\
\text { better than CCC in improving spiritual } \\
\text { wellbeing and better than SPC in } \\
\text { lessening sadness/depression. }\end{array}$ & $\begin{array}{l}\text { - Persons } \\
\text { with } \\
\text { palliative } \\
\text { care needs }\end{array}$ \\
\hline $\begin{array}{l}\text { Hall et al. (2009a) } \\
\text { (S6) }\end{array}$ & $\begin{array}{l}\text { To assess the feasibility, } \\
\text { acceptability and effectiveness of } \\
\text { DT to reduce psychological and } \\
\text { spiritual distress in older people } \\
\text { reaching the end of life in care } \\
\text { homes and to pilot the methods } \\
\text { for a phase III RCT. }\end{array}$ & $\begin{array}{l}\text { A phase II RCT. Study protocol. } \\
\text { Older people }(n=64) \text { reaching the } \\
\text { end of life in care homes, in the UK. }\end{array}$ & $\begin{array}{l}\text { I: DT }(n=32) \text {. } \\
\text { C: standard care }(n=32) \text {. } \\
\text { D: outcome measures and } \\
\text { semi-structured interviews. }\end{array}$ & $\begin{array}{l}\text { No results are available because this is a } \\
\text { study protocol. }\end{array}$ & $\begin{array}{l}\text { - Persons } \\
\text { with } \\
\text { palliative } \\
\text { care needs } \\
\text { - Their } \\
\text { relatives } \\
\text { and friends }\end{array}$ \\
\hline $\begin{array}{l}\text { Hall et al. (2009b) } \\
\text { (S7) }\end{array}$ & $\begin{array}{l}\text { To assess the feasibility, } \\
\text { acceptability and potential } \\
\text { effectiveness of DT to reduce } \\
\text { psychological and spiritual distress } \\
\text { in advanced cancer patients and to } \\
\text { pilot the methods in a phase III } \\
\text { RCT. }\end{array}$ & $\begin{array}{l}\text { A feasibility study with a qualitative } \\
\text { and quantitative approach. Study } \\
\text { protocol. } \\
\text { Patients with advanced cancer } \\
(n=40) \text { in hospital-based palliative } \\
\text { care teams in the UK. }\end{array}$ & $\begin{array}{l}\text { I: DT offered in addition to } \\
\text { standard care }(n=20) . \\
\text { C: standard care }(n=20) \text {. } \\
\text { D: outcome measures. }\end{array}$ & $\begin{array}{l}\text { No results are available because this is a } \\
\text { study protocol. }\end{array}$ & $\begin{array}{l}\text { - Persons } \\
\text { with } \\
\text { palliative } \\
\text { care needs } \\
\text { - Their } \\
\text { relatives }\end{array}$ \\
\hline $\begin{array}{l}\text { Hall et al. (2011a) } \\
\text { (S8) }\end{array}$ & $\begin{array}{l}\text { To assess feasibility, acceptability, } \\
\text { and potential effectiveness of DT } \\
\text { to reduce distress in older people } \\
\text { in care homes. }\end{array}$ & $\begin{array}{l}\text { A phase II RCT. } \\
\text { Residents aged } 65+(n=60) \text { with no } \\
\text { major cognitive impairment in care } \\
\text { homes in the UK. }\end{array}$ & $\begin{array}{l}\text { I: DT }(n=31) . \\
\text { C: standard psychological care } \\
(n=29) . \\
\text { D: outcome measures. }\end{array}$ & $\begin{array}{l}\text { - Residents receiving DT more strongly } \\
\text { agreed it had helped them, made their } \\
\text { life more meaningful, heightened their } \\
\text { sense of purpose, lessened their } \\
\text { suffering, increased their will to live, } \\
\text { and had helped or would help their } \\
\text { families (significant for feeling DT } \\
\text { made life more meaningful at } \\
\text { two-week follow-up, and that it would } \\
\text { help their families at both follow-ups). } \\
\text { No significant differences between } \\
\text { groups on measures of potential } \\
\text { effectiveness at any time. Small effects } \\
\text { at T2 in favor of DT on depression and } \\
\text { quality of life (EQ-5D only). The control } \\
\text { group was more hopeful at T3; a } \\
\text { reduction was seen in dignity-related } \\
\text { distress in both groups. }\end{array}$ & $\begin{array}{l}\text { - Persons } \\
\text { with } \\
\text { palliative } \\
\text { care needs }\end{array}$ \\
\hline
\end{tabular}




\begin{tabular}{|c|c|c|c|c|c|}
\hline $\begin{array}{l}\text { Hall et al. (2011b) } \\
\text { (S9) }\end{array}$ & $\begin{array}{l}\text { To assess the ability of DT to } \\
\text { reduce distress in advanced cancer } \\
\text { patients. }\end{array}$ & $\begin{array}{l}\text { A randomized phase II trial. Adults } \\
\text { with advanced cancer }(n=45) \text { within } \\
\text { two hospital-based palliative care } \\
\text { teams in the UK. }\end{array}$ & $\begin{array}{l}\text { I: DT }(n=22) \text {. } \\
\text { C: SPC }(n=23) \text {. } \\
\text { D: outcome measures and } \\
\text { ratings of benefits of DT. }\end{array}$ & $\begin{array}{l}\text { - Groups did not differ in dignity-related } \\
\text { distress at any time but there was a } \\
\text { slight reduction in dignity-related } \\
\text { distress in the control group at } \\
\text { one-week follow-up. The DT group } \\
\text { showed higher levels of hope than the } \\
\text { control group at both follow-ups. Effect } \\
\text { sizes = medium, significant at } \\
\text { one-week follow-up. } \\
\text { - Groups did not differ on measures of } \\
\text { anxiety, depression, quality of life or } \\
\text { palliative outcomes. } \\
\text { The DT group was more positive than } \\
\text { the control group on all self-reported } \\
\text { benefits ratings (e.g. DT had helped). }\end{array}$ & $\begin{array}{l}\text { - Persons } \\
\text { with } \\
\text { palliative } \\
\text { care needs }\end{array}$ \\
\hline $\begin{array}{l}\text { Houmann et al. } \\
\text { (2014) } \\
\text { (S10) }\end{array}$ & $\begin{array}{l}\text { To investigate participation in and } \\
\text { evaluation of DT and longitudinal } \\
\text { changes in patient-rated } \\
\text { outcomes. }\end{array}$ & $\begin{array}{l}\text { A prospective, pre-/post-evaluation } \\
\text { design. } \\
\text { Eligible patients with incurable } \\
\text { cancer }(80 / 341) \text { were included at a } \\
\text { hospice and a hospital palliative } \\
\text { medicine unit in Denmark. }\end{array}$ & $\begin{array}{l}\text { I: DT. } \\
\text { C: no control group. } \\
\text { D: questionnaires and outcome } \\
\text { measures. }\end{array}$ & $\begin{array}{l}\text { - Of patients, } 73-89 \% \text {, found DT helpful, } \\
\text { satisfactory and helpful to relatives. } 47- \\
56 \% \text { reported DT heightened their sense } \\
\text { of purpose, dignity and will to live. } \\
\text { - Quality of life decreased and depression } \\
\text { increased on one of several depression } \\
\text { measures. Dignity and sense of being a } \\
\text { burden to others improved. }\end{array}$ & $\begin{array}{l}\text { - Persons } \\
\text { with } \\
\text { palliative } \\
\text { care needs }\end{array}$ \\
\hline $\begin{array}{l}\text { Johns (2013) } \\
\text { (S11) }\end{array}$ & $\begin{array}{l}\text { To translate DT into clinical } \\
\text { practice in a cancer center in } \\
\text { Midwestern USA. }\end{array}$ & $\begin{array}{l}\text { A quantitative study with baseline/ } \\
\text { post-intervention measures. Adult } \\
\text { women }(n=10) \text { with metastatic } \\
\text { cancer recruited from a local } \\
\text { support group or by their medical } \\
\text { team. Two patients were seen in } \\
\text { their homes, while eight patients } \\
\text { took part in the outpatient clinic. }\end{array}$ & $\begin{array}{l}\text { I: DT. } \\
\text { C: no control group. } \\
\text { D: baseline and } \\
\text { post-intervention measures } \\
\text { (completed by four women), } \\
\text { satisfaction survey for both the } \\
\text { women and their family } \\
\text { members }(n=6) \text {. }\end{array}$ & $\begin{array}{l}\text { - Of patients, } 75 \% \text { said DT had been } \\
\text { helpful to them and their families, and } \\
\text { thought DT made their life more } \\
\text { meaningful. Although completers had } \\
\text { minimal problems with loss of dignity } \\
\text { or suffering at baseline, } 75 \% \text { reported } \\
\text { DT was helpful in these areas. } \\
\text { - Desire for death, lack of wellbeing and } \\
\text { loss of dignity slightly decreased from } \\
\text { baseline. Mean depression scores } \\
\text { increased by } 29 \% \text {, anxiety increased by } \\
50 \%, \text { HRQoL declined by } 11 \% \text {, } \\
\text { existential distress remained relatively } \\
\text { stable. Post-intervention scores might } \\
\text { have been influenced by that half the } \\
\text { completers }(n=2) \text { had been informed } \\
\text { of significant disease progression. }\end{array}$ & $\begin{array}{l}\text { - Persons } \\
\text { with } \\
\text { palliative } \\
\text { care needs } \\
\text { - Relatives }\end{array}$ \\
\hline $\begin{array}{l}\text { Julião et al. (2013) } \\
\text { (S12) }\end{array}$ & $\begin{array}{l}\text { To determine the effect of DT on } \\
\text { symptoms of depression and } \\
\text { anxiety in people with a } \\
\text { life-threatening disease and with } \\
\text { high level of distress, referred to an } \\
\text { inpatient palliative care unit. }\end{array}$ & $\begin{array}{l}\text { An open-label RCT. } \\
\text { Terminally ill patients }(n=60) \text { from } \\
\text { an inpatient palliative care unit in } \\
\text { Portugal. }\end{array}$ & $\begin{array}{l}\text { I: DT + SPC }(n=29) \\
\text { C: SPC }(n=31) \text {. } \\
\text { D: outcome measurements. }\end{array}$ & $\begin{array}{l}\text { DT seems to have a short-term } \\
\text { beneficial effect on depression and } \\
\text { anxiety for terminally ill patients. } \\
\text { - DT was associated with a significant } \\
\text { decrease in depressive symptoms at } \\
\text { day } 4 \text { and day } 15 \text { but not day } 30 \text {. In the } \\
\text { SPC group, a significant increase in } \\
\text { depression was observed. DT was } \\
\text { associated with a significant decrease } \\
\text { in anxiety. In the SPC group, no } \\
\text { significant changes were found in } \\
\text { HADS scores. }\end{array}$ & $\begin{array}{l}\text { - Persons } \\
\text { with } \\
\text { palliative } \\
\text { care needs }\end{array}$ \\
\hline
\end{tabular}


Table 4. (Continued.)

\begin{tabular}{|c|c|c|c|c|c|}
\hline Study & Aim & $\begin{array}{l}\text { Design } \\
\text { Sample } \\
\text { Setting }\end{array}$ & $\begin{array}{c}\text { Intervention (I) } \\
\text { Control (C) } \\
\text { Data collection (D) }\end{array}$ & Key findings & Perspective \\
\hline $\begin{array}{l}\text { Julião et al. (2014) } \\
\text { (S13) }\end{array}$ & $\begin{array}{l}\text { To determine the influence of DT } \\
\text { on depression and anxiety in } \\
\text { inpatients with a terminal } \\
\text { illness experiencing a high level of } \\
\text { distress in a palliative care unit. }\end{array}$ & $\begin{array}{l}\text { A phase II RCT. } \\
\text { Patients }(n=80) \text {, most of them with } \\
\text { cancer, from a specialized palliative } \\
\text { medicine unit in Portugal. }\end{array}$ & $\begin{array}{l}\text { I: DT + SPC }(n=39) \\
\text { C: SPC }(n=41) . \\
\text { D: outcome measurements. }\end{array}$ & $\begin{array}{l}\text { - The DT group compared with the SPC } \\
\text { group revealed significantly less } \\
\text { depression at all assessment points. } \\
\text { - The DT group demonstrated } \\
\text { significantly lower anxiety than the } \\
\text { SPC group at all assessment points. }\end{array}$ & $\begin{array}{l}\text { - Persons } \\
\text { with } \\
\text { palliative } \\
\text { care needs }\end{array}$ \\
\hline $\begin{array}{l}\text { Julião et al. (2017) } \\
\text { (S14) }\end{array}$ & $\begin{array}{l}\text { To determine the influence of DT } \\
\text { on DS, the desire for death (DfD), } \\
\text { and a sense of dignity (SoD) in } \\
\text { terminally ill } \\
\text { inpatients experiencing a high level } \\
\text { of distress in a palliative care unit. }\end{array}$ & $\begin{array}{l}\text { A non-blinded phase II RCT. } \\
\text { Terminally ill inpatients with high } \\
\text { levels of distress in a palliative care } \\
\text { unit }(n=80) \text { in Portugal. }\end{array}$ & $\begin{array}{l}\text { I: DT }+ \text { SPC }(n=41) \\
\text { C: SPC }(n=39) \\
\text { D: outcome measures. }\end{array}$ & $\begin{array}{l}\text { - DT had a beneficial effect on } \\
\text { psychological distress in patients near } \\
\text { the end of life. } \\
\text { - DT was associated with a significant } \\
\text { decrease in DS compared with SPC. DT } \\
\text { was associated with a significant } \\
\text { decrease in DfD prevalence. } \\
\text { - Compared with the control group, } \\
\text { those receiving DT showed a } \\
\text { statistically significant reduction in 19/ } \\
25 \text { PDI items (PDI measuring the sense } \\
\text { of dignity). }\end{array}$ & $\begin{array}{l}\text { - Persons } \\
\text { with } \\
\text { palliative } \\
\text { care needs }\end{array}$ \\
\hline $\begin{array}{l}\text { Montross-Thomas } \\
\text { et al. (2015) } \\
\text { (S15) }\end{array}$ & $\begin{array}{l}\text { To determine whether DT } \\
\text { enhances positive outcomes in } \\
\text { hospice and palliative care } \\
\text { populations. }\end{array}$ & $\begin{array}{l}\text { A mixed-methods RCT. Study } \\
\text { protocol. Patients }(n=90) \text { with } \\
\text { cancer receiving hospice or palliative } \\
\text { care from care teams in the USA. }\end{array}$ & $\begin{array}{l}\text { I: DT ( } n=45) \text {. } \\
\text { C: a supportive attention group } \\
(n=45) \text {. } \\
\text { D: outcome measurements. } \\
\text { A questionnaire. Qualitative } \\
\text { interviews. }\end{array}$ & $\begin{array}{l}\text { No results are available because this is a } \\
\text { study protocol. }\end{array}$ & $\begin{array}{l}\text { - Persons } \\
\text { with } \\
\text { palliative } \\
\text { care needs }\end{array}$ \\
\hline $\begin{array}{l}\text { Passik et al. (2004) } \\
\text { (S16) }\end{array}$ & $\begin{array}{l}\text { To determine whether } \\
\text { telemedicine is a feasible way to } \\
\text { make dignity psychotherapy } \\
\text { available to patients dying at } \\
\text { home. }\end{array}$ & $\begin{array}{l}\text { A feasibility study with a quantitative } \\
\text { method. } \\
\text { Cancer patients }(n=8) \text { enrolled in a } \\
\text { hospice or palliative care program } \\
\text { receiving DT in their homes in the } \\
\text { USA. }\end{array}$ & $\begin{array}{l}\text { I: DT delivered via videophone } \\
\text { technology. } \\
\text { C: no control group. } \\
\text { D: baseline assessments and } \\
\text { follow-up questionnaires, } \\
\text { single-item screens, satisfaction } \\
\text { survey. }\end{array}$ & $\begin{array}{l}\text { - Participants reported overall benefit } \\
\text { and a high level of satisfaction. } \\
\text { Delivering DT with telemedicine } \\
\text { extended the benefits of } D T \text {, bringing it } \\
\text { to patients. } \\
\text { - Mean scores: the Zung } 43.0(S D=10.62) \\
\text { at baseline and } 47.86(S D=9.12) \text { at } \\
\text { study end, PUB scale } 30.13(S D=7.57) \\
\text { at baseline and } 35.0(S D=6.46) \text { at } \\
\text { study end, lack of dignity or } \\
\text { self-respect } 3.75(S D=1.83) \text { at baseline } \\
\text { and } 2.14(S D=1.95) \text { at study end. }\end{array}$ & $\begin{array}{l}\text { - Persons } \\
\text { with } \\
\text { palliative } \\
\text { care needs }\end{array}$ \\
\hline
\end{tabular}




\begin{tabular}{|c|c|c|c|c|c|}
\hline $\begin{array}{l}\text { Rudilla et al. (2016) } \\
\text { (S17) }\end{array}$ & $\begin{array}{l}\text { To examine the effects of DT and } \\
\text { counselling and to offer useful } \\
\text { information that could be put into } \\
\text { practice to better meet patients' } \\
\text { needs. }\end{array}$ & $\begin{array}{l}\text { An RCT. } \\
\text { A sample of palliative care patients } \\
(n=70) \text { from a home care unit at the } \\
\text { Hospital General Universitario de } \\
\text { Valencia, Spain. }\end{array}$ & $\begin{array}{l}\text { I: DT }(n=35) \text {. } \\
\text { C: counselling }(n=35) \text {. } \\
\text { D: outcome measurements and } \\
\text { questionnaires. }\end{array}$ & $\begin{array}{l}\text { - The study provided evidence for the } \\
\text { efficacy of DT and counselling in } \\
\text { improving wellbeing. Statistically } \\
\text { significant differences were found in } \\
\text { dimensions of dignity, anxiety, } \\
\text { spirituality, and quality of life for both } \\
\text { groups. } \\
\text { Better results were reported in the } \\
\text { counselling group with respect to } \\
\text { depression, resilience, and anxiety. }\end{array}$ & $\begin{array}{l}\text { - Persons } \\
\text { with } \\
\text { palliative } \\
\text { care needs }\end{array}$ \\
\hline $\begin{array}{l}\text { Scarton et al. } \\
\text { (2018) } \\
\text { (S18) }\end{array}$ & $\begin{array}{l}\text { The purpose of this secondary } \\
\text { analysis study was to examine } \\
\text { properties of a new measure of } \\
\text { dignity impact. }\end{array}$ & $\begin{array}{l}\text { A study using the DIS to reanalyze } \\
\text { post-test data from a large } \\
\text { three-arm, multi-site RCT study. } \\
\text { Participants from hospice/palliative } \\
\text { care }(n=326) \text { with a terminal illness } \\
\text { in the USA and Canada. }\end{array}$ & $\begin{array}{l}\text { I: DT }(n=108) \text {. } \\
\text { C: SPC }(n=111) \text { or } \\
\text { Client-Centred Care }(n=107) \text {. } \\
\text { D: outcome measures. }\end{array}$ & $\begin{array}{l}\text { - Compared with both other groups, the } \\
\text { DT group reported significantly higher } \\
\text { DIS ratings. } \\
\text { - It is proposed that the DIS be used as } \\
\text { the primary outcome measure for } \\
\text { evaluating effects of DT. }\end{array}$ & $\begin{array}{l}\text { - Persons } \\
\text { with } \\
\text { palliative } \\
\text { care needs }\end{array}$ \\
\hline $\begin{array}{l}\text { Vergo et al. (2014) } \\
\text { (S19) }\end{array}$ & $\begin{array}{l}\text { To assess the feasibility of DT } \\
\text { relatively early in the disease } \\
\text { trajectory (primary endpoint) and } \\
\text { the effect on death acceptance, } \\
\text { distress, symptoms, quality of life, } \\
\text { peacefulness, and advanced care } \\
\text { planning (secondary outcome } \\
\text { endpoint). }\end{array}$ & $\begin{array}{l}\text { A feasibility study with a quantitative } \\
\text { design. } \\
\text { Patients with stage IV colorectal } \\
\text { cancer }(n=9) \text { who progressed on } \\
\text { first-line chemotherapy at an } \\
\text { outpatient oncology clinic in the } \\
\text { USA. }\end{array}$ & $\begin{array}{l}\text { I: DT. } \\
\text { C: no control group. } \\
\text { D: outcome measures. } \\
\text { Feasibility assessed by success } \\
\text { rate and a satisfaction survey. }\end{array}$ & $\begin{array}{l}\text { - Participants were satisfied and felt DT } \\
\text { was helpful; it increased sense of } \\
\text { meaning (88\%), sense of dignity (78\%), } \\
\text { sense of purpose (78\%), and } \\
\text { participants' will to live (67\%) and was } \\
\text { deemed helpful for families (88\%). } \\
\text { - Regarding physical symptoms, only } \\
\text { appetite seemed to improve. With } \\
\text { regard to emotional symptoms, no } \\
\text { negative impact of DT was noted. } \\
\text { There also seemed to be an increase in } \\
\text { death acceptance over time. A change } \\
\text { was found in non-life-prolonging goals } \\
\text { of care and in treatment choices over } \\
\text { time (shift from undecided to } \\
\text { non-life-prolonging) (non-significant). }\end{array}$ & $\begin{array}{l}\text { - Persons } \\
\text { with } \\
\text { palliative } \\
\text { care needs }\end{array}$ \\
\hline
\end{tabular}

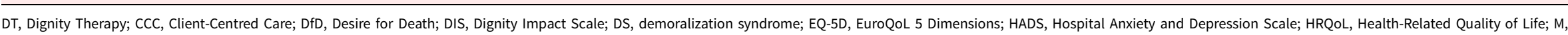

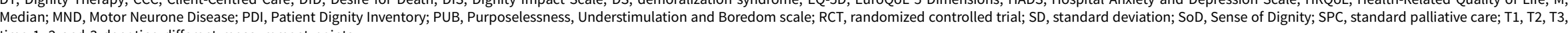
time 1,2 and 3 denoting different measurement points. 
Table 5. Articles $(n=7)$ focusing on interventions for dignity-conserving care, other than DT

\begin{tabular}{|c|c|c|c|c|c|}
\hline Study & Aim & $\begin{array}{l}\text { Design } \\
\text { Sample } \\
\text { Setting }\end{array}$ & $\begin{array}{l}\text { Intervention (I) } \\
\quad \text { Control (C) } \\
\text { Data collection (D) }\end{array}$ & Key findings & $\begin{array}{c}\text { Article } \\
\text { perspective }\end{array}$ \\
\hline $\begin{array}{l}\text { Chochinov } \\
\text { et al. (2015) } \\
\text { (S20) }\end{array}$ & $\begin{array}{l}\text { To evaluate the impact of the PDQ on } \\
\text { patients and families, evaluate its } \\
\text { influence on healthcare providers } \\
\text { (HCPs), and determine whether HCP } \\
\text { characteristics mediate receptivity to } \\
\text { PDQ-elicited information. }\end{array}$ & $\begin{array}{l}\text { A quantitative study. } \\
\text { Palliative care patients ( } n=66) \text { and } \\
\text { family members }(n=60) \text { in } \\
\text { inpatient care at palliative care } \\
\text { facilities in Canada. Health care } \\
\text { professionals }(n=137) \text { completed } \\
\text { evaluations of individual PDQs. }\end{array}$ & $\begin{array}{l}\text { I: PDQ tool. } \\
\text { C: no control group. } \\
\text { D: questionnaires, outcome } \\
\text { measures and a survey. }\end{array}$ & $\begin{array}{l}\text { - The PDQ stimulates personhood. } \\
\text { Patients and family members ( } 93 \%) \\
\text { indicated that PDQ information was } \\
\text { important for HCPs to know. } \\
\text { - Health care providers }(90 \%) \text { indicated } \\
\text { learning something new; } 64 \% \text { were } \\
\text { emotionally affected; it influenced } \\
\text { their sense of empathy ( } 59 \%) \text {, } \\
\text { attitude (56\%), personal satisfaction } \\
\text { with providing care }(49 \%) \text { and respect } \\
\text { towards patients }(48 \%) \text { and how they } \\
\text { provided care }(44 \%) \text {. }\end{array}$ & $\begin{array}{l}\text { - Persons with } \\
\text { - palliative } \\
\text { care needs } \\
\text { - Their } \\
\text { relatives } \\
\text { - Health care } \\
\text { professionals }\end{array}$ \\
\hline $\begin{array}{l}\text { Da Rocha } \\
\text { Rodrigues } \\
\text { et al. (2016) } \\
\text { (S21) }\end{array}$ & $\begin{array}{l}\text { To explore the feasibility of the Revie } \oplus \\
\text { intervention, a life review intervention } \\
\text { comprising a positive, patient-centred } \\
\text { approach, and to determine potential } \\
\text { changes in patients' sense of dignity, } \\
\text { post-traumatic growth, and satisfaction } \\
\text { with life. }\end{array}$ & $\begin{array}{l}\text { A feasibility study using mixed- } \\
\text { method research. Study protocol. } \\
\text { Patients with advanced cancer }(n= \\
\text { 40) recruited within the ambulatory } \\
\text { and inpatient oncology setting of a } \\
\text { university hospital in Switzerland. }\end{array}$ & $\begin{array}{l}\text { I: Revie } \oplus \text {, a life review } \\
\text { intervention with a positive, } \\
\text { patient-centred approach. } \\
\text { C: no control group. } \\
\text { D: pre- and post-measurements. } \\
\text { Semi-directed interviews. }\end{array}$ & $\begin{array}{l}\text { - No results are available because this } \\
\text { is a study protocol. }\end{array}$ & $\begin{array}{l}\text { - Persons with } \\
\text { palliative } \\
\text { care needs } \\
\text { - Health care } \\
\text { professionals }\end{array}$ \\
\hline $\begin{array}{l}\text { Ho et al. } \\
\text { (2016) } \\
\text { (S22) }\end{array}$ & $\begin{array}{l}\text { To describe the development and } \\
\text { implementation mechanisms of a novel } \\
\text { Dignity-Conserving End of Life (EoL) Care } \\
\text { model successfully adopted by three } \\
\text { nursing homes in Hong Kong, and } \\
\text { present preliminary evidence of its } \\
\text { effectiveness on enhancing dignity and } \\
\text { quality of life (QoL) of terminally ill } \\
\text { residents. }\end{array}$ & $\begin{array}{l}\text { A quantitative study. } \\
\text { Residents }(n=9) \text { with cancer, } \\
\text { chronic obstructive pulmonary } \\
\text { disease, chronic heart failure, } \\
\text { chronic renal failure, liver disease, } \\
\text { stroke, neurological conditions, } \\
\text { and chronic frailty from nursing } \\
\text { homes in China. }\end{array}$ & $\begin{array}{l}\text { I: a Dignity-Conserving End of Life } \\
\text { Care program with } 10 \text { core service } \\
\text { elements. } \\
\text { C: no control group. } \\
\text { D: outcome measurements. } \\
\text { Wilcoxon's signed-rank test was } \\
\text { used to detect significant changes } \\
\text { in each of the Quality of Life } \\
\text { domains across time. }\end{array}$ & $\begin{array}{l}\text { - Findings demonstrated usefulness of } \\
\text { the Dignity-Conserving End of Life } \\
\text { Care model. } \\
\text { - Results showed significant } \\
\text { deterioration in physical Quality of } \\
\text { Life and significant improvement of } \\
\text { social Quality of Life. A clear trend } \\
\text { towards significant improvements } \\
\text { was identified for the Quality of Life } \\
\text { domains of relationships and } \\
\text { individuality. }\end{array}$ & $\begin{array}{l}\text { - Persons with } \\
\text { palliative } \\
\text { care needs }\end{array}$ \\
\hline $\begin{array}{l}\text { Ho et al. } \\
\text { (2017) } \\
\text { (S23) }\end{array}$ & $\begin{array}{l}\text { To assess the feasibility, acceptability, } \\
\text { and potential effectiveness of the FDI in } \\
\text { reducing psychosocial, emotional, } \\
\text { spiritual, and psychophysiological } \\
\text { distress in community-dwelling patients } \\
\text { and inpatients, older terminally ill Asian } \\
\text { patients and their families living in } \\
\text { Singapore. }\end{array}$ & $\begin{array}{l}\text { An open-label RCT. Study protocol. } \\
\text { Asian families ( } n=126) \text { recruited } \\
\text { from hospice services and their } \\
\text { satellite centers (both inpatients } \\
\text { and home care). Each family } \\
\text { included a patient-family dyad of } \\
\text { an older terminally ill person and a } \\
\text { family member in Singapore. }\end{array}$ & $\begin{array}{l}\text { I: the FDI builds upon the clinical } \\
\text { foundation of DT. } \\
\text { C: standard psychological care. } \\
\text { D: interviews and outcome } \\
\text { measures. }\end{array}$ & $\begin{array}{l}\text { - No results are available because this } \\
\text { is a study protocol. }\end{array}$ & $\begin{array}{l}\text { - Persons with } \\
\text { palliative } \\
\text { care needs } \\
\text { - Their } \\
\text { relatives } \\
\text { (family } \\
\text { members) }\end{array}$ \\
\hline
\end{tabular}




\begin{tabular}{|c|c|c|c|c|c|}
\hline $\begin{array}{l}\text { Johnston } \\
\text { et al. (2015a) } \\
\text { (S24) }\end{array}$ & $\begin{array}{l}\text { To assess the feasibility and } \\
\text { acceptability of the PDQ: "What do I } \\
\text { need to know about you as a person to } \\
\text { take the best care of you that I can?," as } \\
\text { a person-centred intervention for } \\
\text { patients with palliative care needs. }\end{array}$ & $\begin{array}{l}\text { A feasibility study with qualitative } \\
\text { and quantitative design. } \\
\text { Patients with palliative care needs } \\
(n=9) \text { in an acute hospital setting } \\
\text { in Scotland, UK. Health care } \\
\text { providers involved in care also took } \\
\text { part }(n=5) \text {. }\end{array}$ & $\begin{array}{l}\text { I: PDQ tool. } \\
\text { C: no control group. } \\
\text { D: questionnaires and outcomes, } \\
\text { qualitative interviews. }\end{array}$ & $\begin{array}{l}\text { - Participants found the PDQ } \\
\text { acceptable. The environment was } \\
\text { relatively person-centred (but the } \\
\text { physical environment and the time } \\
\text { HCPs had for patients were poorly } \\
\text { rated). Patients felt that PDQ } \\
\text { information was important for HCPs } \\
\text { to know; } 66.6 \% \text { agreed that it affects } \\
\text { the way they are cared for. Health } \\
\text { care providers learned new things } \\
\text { about patients but felt that this could } \\
\text { not influence their respect towards } \\
\text { them (they already respected them). }\end{array}$ & $\begin{array}{l}\text { - Persons with } \\
\text { palliative } \\
\text { care needs } \\
\text { - Health care } \\
\text { professionals }\end{array}$ \\
\hline $\begin{array}{l}\text { Johnston } \\
\text { et al. (2015c) } \\
\text { (S25) }\end{array}$ & $\begin{array}{l}\text { To inform a larger, future multi-site } \\
\text { study, this study tests the hypothesis } \\
\text { that the PDQ intervention could be used } \\
\text { to enhance a more person-centred } \\
\text { climate for people with palliative care } \\
\text { needs in the acute hospital setting, and } \\
\text { provide evidence regarding its } \\
\text { acceptability. }\end{array}$ & $\begin{array}{l}\text { A mixed-method pilot study. } \\
\text { Patients ( } n=30) \text { with palliative care } \\
\text { needs, family members }(n=4) \text {, and } \\
\text { HCPs }(n=17) \text { from acute care } \\
\text { wards in Scotland, UK. A specialist } \\
\text { palliative care team offers support } \\
\text { across the hospital. Patients can be } \\
\text { transferred to a palliative care unit } \\
\text { or to a hospice. }\end{array}$ & $\begin{array}{l}\text { I: PDQ tool. } \\
\text { C: no control group. } \\
\text { D: before and after measurements } \\
\text { and questionnaires. Qualitative } \\
\text { interviews. }\end{array}$ & $\begin{array}{l}\text { - The PDQ has the potential to improve } \\
\text { patients' perceptions of care and to } \\
\text { affect how HCPs provide care, and } \\
\text { teach them new things about their } \\
\text { patients. } \\
\text { - Individual results from the PCQ-P and } \\
\text { the CARE indicated overall } \\
\text { improvements in the majority of } \\
\text { fields (indicating that PDQ can } \\
\text { improve the person-centred } \\
\text { environment and empathy). Themes } \\
\text { emerging from family members' } \\
\text { responses, for example, included } \\
\text { individualized care and having time } \\
\text { to talk. }\end{array}$ & $\begin{array}{l}\text { - Persons with } \\
\text { palliative } \\
\text { care needs } \\
\text { - Their } \\
\text { relatives } \\
\text { - Health care } \\
\text { professionals }\end{array}$ \\
\hline $\begin{array}{l}\text { Roos et al. } \\
\text { (2016) } \\
\text { (S26) }\end{array}$ & $\begin{array}{l}\text { To examine residents' perceptions of } \\
\text { empowerment, person-centred climate } \\
\text { and life satisfaction before and after a } \\
\text { caregiver intervention concerning the } \\
\text { Swedish national fundamental values. } \\
\text { Further, to investigate whether there } \\
\text { were any differences in change over time } \\
\text { in these variables between an } \\
\text { intervention group and a control group. }\end{array}$ & $\begin{array}{l}\text { A cluster RCT with pre- to post-test } \\
\text { design. Older people }(n=80) \text { in } \\
\text { residential facilities in five } \\
\text { municipalities in Sweden. }\end{array}$ & $\begin{array}{l}\text { I: an intervention targeting } \\
\text { fundamental values among } \\
\text { caregivers }(n=43) \text {. } \\
\text { C: regular care }(n=37) \text {. } \\
\text { D: questionnaires and outcome } \\
\text { measures. }\end{array}$ & $\begin{array}{l}\text { - The intervention increased } \\
\text { empowerment, and improved } \\
\text { person-centred climate and quality of } \\
\text { everyday activities among older } \\
\text { people, while disempowerment } \\
\text { decreased. In the control group, } \\
\text { person-centred climate and quality of } \\
\text { everyday activities decreased. No } \\
\text { significant differences were seen for } \\
\text { empowerment and disempowerment. } \\
\text { - Change over time between groups } \\
\text { was significant for empowerment, } \\
\text { disempowerment, and } \\
\text { person-centred climate and for life } \\
\text { satisfaction regarding the quality of } \\
\text { everyday activities. }\end{array}$ & $\begin{array}{l}\text { - Persons with } \\
\text { palliative } \\
\text { care needs }\end{array}$ \\
\hline
\end{tabular}

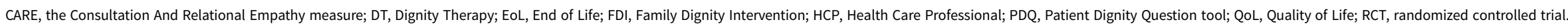


Fig. 2. Harvey Chochinov's dignity model (Chochinov, 2002) with permisson from the developer.

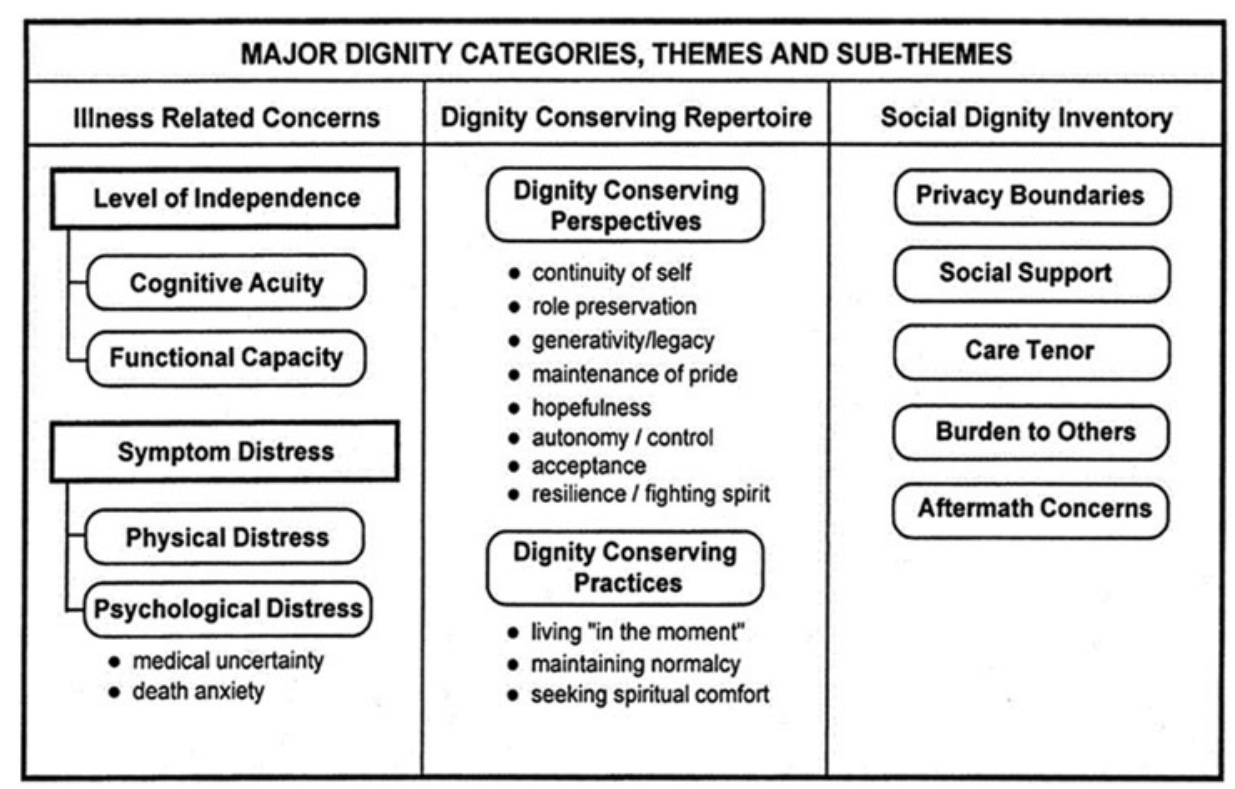

The outcomes "Sense of dignity" (after both $\mathrm{DT}^{\mathrm{S} 14}$ and $\mathrm{FDI}^{\mathrm{S} 23}$ ) and

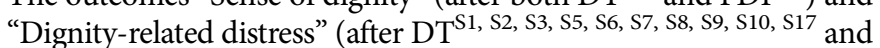
the Revie $\oplus$ intervention ${ }^{\text {S21 }}$ ) were reported in several articles as studied or proposed using the PDI. Other outcomes studied within this theme post-DT were "Gratitude" and "Appreciation of life," proposed to be operationalized through the Gratitude Questionnaire Six-Item Form (GQ-6) ${ }^{\mathrm{S} 15}$ (measuring the experience of gratitude, forgiveness, and spiritual transcendence) or through the 5-item Appreciation of Life subscale and one subscale of the Life Evaluation Questionnaire. ${ }^{\text {S15 }}$

\section{Aspects of quality of life}

Another theme with a broad focus on dignity issues was "Aspects of quality of life." The "Quality of life" was studied after administering DT, FDI, and the Dignity-Conserving End of Life Care Program. It was operationalized or proposed through the Amyotrophic Lateral Sclerosis Assessment Questionnaire-5 (ALSAQ-5) $^{\mathrm{S} 1}$, a Quality of Life Scale (measuring the quality of life and satisfaction with the quality of life) ${ }^{\mathrm{S} 4}, \mathrm{~S} 5, \mathrm{~S} 6, \mathrm{~S} 7, \mathrm{~S} 8, \mathrm{~S} 9, \mathrm{~S} 19$, and the EuroQoL 5 Dimension (EQ-5D) instrument ${ }^{\mathrm{S},}$, s7, s8, s9 and also by two items from the European Organization for Research and Treatment of Cancer Quality of Life C30

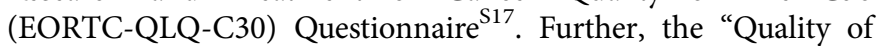
life" was proposed or studied through the McGill Quality of Life Questionnaire ${ }^{\text {S22 }}$ or through the WHO Quality of Life Scale- 8 S23. The outcome "Satisfaction with life" was proposed after the implementation of the Revie $\oplus$ intervention using the Satisfaction with Life Scale ${ }^{\mathrm{S} 21}$ or studied after the intervention targeting fundamental values with the Life Satisfaction Questionnaire (the LSQ) ${ }^{\mathrm{S} 26}$. "Health-related quality of life" was another outcome studied (after DT) within this theme through the use of the EORTC Quality of Life Questionnaire-C15-PAL (15 items for palliative care $)^{\mathrm{S} 10}$ or the Functional Assessment of Chronic Illness Therapy-Palliative Care version 4 (FACIT-Pal) ${ }^{\text {S11 }}$. Investigators also proposed to study "Nursing home quality of life" through the Nursing Facilities Quality of Life scale after the implementation of the Dignity-Conserving End of Life Care Program ${ }^{\text {S22 }}$.

\section{Discussion}

This integrative review identified outcomes that were grouped under seven themes and four cluster themes (Table 7). All identified outcomes could be related to Chochinov's dignity model (Chochinov, 2002). To be able to maintain or enhance a person's dignity, outcomes related to all three main categories are suggested to be studied together to provide high-quality dignity-conserving care. Otherwise, there is a risk that some part of a person's dignity could be unconfirmed. Loss of dignity has been related to different factors: symptom and existential distress, dependency, absence of peace of mind, and a lack of social support (Rudilla et al., 2016). This strengthens the assumption of using a broad focus on outcomes while evaluating dignityconserving care. This review identified "Themes related to Illness-Related Concerns" as the most common cluster theme, implying the need for a broader perspective also including outcomes related to the other cluster themes, "Themes related to the Dignity-Conserving Repertoire" and "Themes related to the Social Dignity Inventory." Other studies also recommend the use of a holistic approach to studying outcomes (Evans et al., 2013; Akpan et al., 2018), which implies that outcomes identified within "Themes regarding Overarching Dignity Issues" have to be considered in order not to get a too one-sided picture of the concerns of persons with palliative care needs. Previously, Patient-Reported Outcome Measures (PROMs) that were specifically developed to address dignity-conserving care and that are recommended for researchers and clinicians were identified (Johnston et al., 2017a) to be the PDI (Chochinov et al., 2008) and the Missoula-VITAS Quality of Life Index (Byock and Merriman, 1998). In this review, we identified "Dignity-related distress" operationalized through the PDI, as an outcome frequently studied when evaluating dignity-conserving care. By contrast, the Missoula-VITAS Quality of Life Index was not used in any of the studies, suggesting that this instrument may need more attention. Instead, other instruments measuring aspects of quality of life were identified in this review, for example, the McGill Quality of Life Questionnaire ${ }^{\mathrm{S} 22}$ (Cohen et al., 2017) which has shown strong psychometric properties and has previously been recommended (Selman et al., 2011). 


\begin{tabular}{|c|c|}
\hline $\begin{array}{l}\text { Intervention } \\
\text { Theoretical framework (Tf) }\end{array}$ & Content \\
\hline DT & $\begin{array}{l}\text { DT includes a question protocol that guides a recorded therapy } \\
\text { session, where the person can discuss dignity- relevant }\end{array}$ \\
\hline - Dignity model ${ }^{\text {Tf1 }}$ & questions with a therapist. After the session, the therapist \\
\hline $\begin{array}{l}\text { - Meaning-centred approach and the dignity } \\
\text { model }{ }^{\text {Tf2 }}\end{array}$ & $\begin{array}{l}\text { transcribes the session into a manuscript which after a few days } \\
\text { is delivered back to the person who received the therapy, who }\end{array}$ \\
\hline - The dignity model and spiritual care ${ }^{\mathrm{T} f 3}$ & \\
\hline
\end{tabular}

- The dignity model, and $T I^{T+4}$

\section{FDI}

- Dignity model ${ }^{T f 1}$
The FDI is based on the DT protocol, but instead of individual therapy, the FDI targets patient-family dyads to facilitate open dialog between patients and their family caregivers. It aims to strengthen the family connectedness and compassion through creating a supportive platform. The ultimate goal of the FDI is to offer a viable dignity-enhancing intervention to promote holistic palliative care that addresses psycho-socio-spiritual needs of families.

\section{PDQ}

- Personhood, model for empathy, reflection, profession and trust, the nature of suffering and the goals of medicine ${ }^{\text {Tf5 }}$

- Person-centred nursing theory and practice

and the dignity model ${ }^{\text {Tf }}$

- Compassion in practice - nursing ${ }^{\text {Tf7 }}$

\section{Revie $\oplus$ life review intervention}

- A positive patient-centred approach ${ }^{\text {Tf }}$

The PDQ embraces the question "What do I need to know about you as a person to give you the best care possible?" to establish what aspects of personhood are important to the patient and what they would like health care professionals to know about them in order to influence the care they receive. Time schedule: about five to seven days per participant.

The Revie is a person-centred life review intervention for nurses to deliver, including two sessions $(60+15-30 \mathrm{~min})$, to explore how a person's diagnosis has changed the person's values an preferences, and discuss life goals and projects. After the intervention, a booklet is created by the research team, integrating the person's important elements evoked during implementation of the Revie

\section{Dignity-Conserving End-of-Life Care}

A program aimed at enhancing dignity and quality of life in terminally ill residents. Includes 10 core components: a life and death education (1); tailor-made life review intervention (2); asking residents about last wishes and a plan to fulfill these (3); discussions of funeral and memorial preparations (4); psychosocial support for residents' mental wellbeing (5); pain and symptoms management for residents' physical wellbeing (6); routine medical checkups and physical assessments to evaluate disease progression and adjust physical care (7); family meetings with the care team for an update on clinical progress, and to provide support and promote participation (8); making sure that the advance care plan is followed (9); grief and bereavement support to families $(10)$
Reported in article

Hall et al., 2011a (feasibility, RCT) (prospann et al., 2014 (prospective before and after study) Johns, 2013 (quantitative before and after study) Julião et al., 2013

Julião et al., 2014 (RCT) Julião et al., 2017 (RCT)

Montross-Thomas et al., 2015 (mixed-method quantitative $)^{\text {Theoretical frame }}$ Bentley et al., Bernat et al., 2015 (feasibility, Chochinov et al., 2005 (feas qualitative, and quantitative) Chochinov et al., 2011 (RCT) RCT) ${ }^{T f 1}$

Hall et al., 2009b (feasibility, qualitative, and quantitative) Hall et al., 2011b (RCT)

Ho et al., 2017 (feasibility, RCT)

Passik et al., 2004

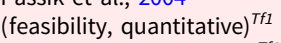
Rudilla et al., 2016 (RCT) Scarton et al., 2018 $(\text { secondary analysis })^{T /}$ Vergo et al., 2014 (feasibility, quantitative) $^{\text {Tf }}$

Chochinov et al., 2015 (quantitative study)

Johnston et al., 2015a (feasibility, qualitative, and quantitative) ${ }^{\text {T/ }}$

Johnston et al., 2015c (mixed-method)

Da Rocha Rodrigues et al., 2016 (feasibility, mixed-method) ${ }^{\text {ff }}$

Ho et al., 2016 (quantitative) $^{T \varphi}$ 


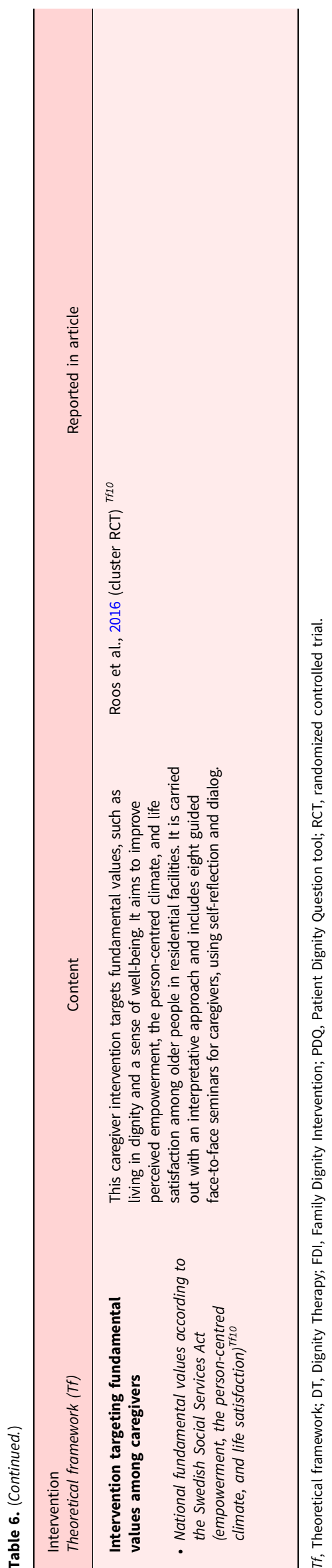

It was not unexpected that "Dignity-related distress" (used in 13 of the articles) and "Quality of life" (used in 16 of the articles) were among the most studied outcomes identified, as these concepts are concrete and central in palliative care (Ho et al., 2014; World Health Organization, 2018). These outcomes have also been listed by other researchers as essential (Johnston et al., 2017a; Akpan et al., 2018). Therefore, health organizations must enable healthcare professionals to emphasize aspects such as these. Healthcare professionals need to know how their patients experience dignity and their quality of life; and if they do not know this, their ability to provide their patients with optimal palliative care could be questioned. Providers of healthcare need to constantly remind themselves to focus on other aspects besides the patient's illnesses - and to see the whole person. It is relevant to mention that a meta-analysis has concluded that psychosocial interventions are effective in improving the quality of life and reducing emotional and existential distress (Warth et al., 2019). Studies with a moderate to the high level of evidence have presented an increased sense of dignity, will to live, and sense of purpose outcomes after DT (Donato et al., 2016). However, effects of DT on dignity and quality of life (Xiao et al., 2019) as well as on physical and emotional symptoms (Fitchett et al., 2015) have been inconsistent. DT has shown efficacy in anxiety and depression outcomes in patients with high levels of psychological distress (Martínez et al., 2017). These outcomes are important and useful - showing that dignity-conserving care could be beneficial for persons with palliative care needs. However, to avoid bias, it is always essential to choose outcomes and measurements that are sensitive to the intervention and to use validated instruments (Bland, 2015). This was lacking in several of the studies and together with a small sample, the design could be questioned.

There is also a need to evaluate effects of other interventions for dignity-conserving care, as one intervention may not be suitable for everyone, and as today tailored care is advocated for, also to use other outcomes for example relating to the care tenor (e.g. person-centered climate). It has been reported that a person with an illness that suffers from multidimensional problems, benefits from a person-centered approach (Grassi et al., 2017), and that a holistic approach (McCance et al., 2011) is suitable for enhancing dignity (Chochinov, 2007).

Further, outcomes within the "Themes related to the Dignity-Conserving Repertoire" can be crucial to evaluate, as it has been reported that loss of dignity is a risk factor for a person's wishing to hasten death (Monforte et al., 2018), which suggests great suffering for that person. Although there are ethical challenges when preserving dignity at the end of life, for example regarding inadequate organization for good palliative care (Brodtkorb et al., 2016), healthcare must assist in trying to prevent people from encountering such suffering. This can, for example, be managed by using relevant outcomes. Further, if healthcare does not give focus to outcomes within "Themes related to the Social Dignity Inventory," for example, empathy, there may be a risk of increasing a person's suffering. It has been stated that insufficient empathy can create a poor connection between the nurse and the patient (Cross, 2019). Patients have described empathy as a response that acknowledges and attempts to understand an individual's suffering (Sinclair et al., 2017). Moreover, both empathy and compassion have been reported by patients as having a positive effect on their care experiences (Sinclair et al., 2017). Attentive nursing care, including paying attention to the person's expressed emotions and narratives, is valuable for providing comforting care (Höglander et al., 2017). Thus, outcomes within the cluster theme "Themes related to the Social 
Table 7. Overview of cluster themes $(n=4)$ and themes $(n=7)$ of studied outcomes in dignity-conserving care

\begin{tabular}{llll}
\hline Cluster themes & \multicolumn{1}{c}{$\begin{array}{c}\text { Themes related to } \\
\text { Illness-Related Concerns }\end{array}$} & $\begin{array}{c}\text { Themes related to the } \\
\text { Dignity-Conserving Repertoire }\end{array}$ & $\begin{array}{l}\text { Themes related to the } \\
\text { Social Dignity Inventory }\end{array}$ \\
\hline $\begin{array}{l}\text { Themes of } \\
\text { studied outcomes }\end{array}$ & $\begin{array}{l}\text { Performance, symptoms and } \\
\text { emotional concerns } \\
\text { End-of-life and existential } \\
\text { aspects }\end{array}$ & $\begin{array}{l}\text { Essential life values } \\
\text { Aspects of personal strength and } \\
\text { coping }\end{array}$ & $\begin{array}{l}\text { Aspects of care tenor } \\
\text { and social support }\end{array}$ \\
\hline
\end{tabular}

Dignity Inventory" must be considered and studied to a greater extent than they have been studied thus far; otherwise, we cannot expect persons' dignity to be well maintained.

In this review, rare outcomes have been identified, such as "gratitude" and "empowerment." As palliative care is often associated with suffering and grief (Chochinov et al., 2007; Aoun et al., 2012), identifying these outcomes may present researchers with a challenge to consider investigating outcomes that are not too obvious. It has been recognized that with a grateful attitude, people may become less fearful of death because they may have a sense that life has been well lived (Lau and Cheng, 2011). Persons with palliative care needs have also reported feeling appreciative about their accomplishments and about important people in their life (Hall et al., 2012), supporting the idea that gratitude could be an important outcome for them. Furthermore, empowerment has been defined as "a process of promoting and enhancing people's ability to meet their own needs and to mobilize the resources necessary to feel control over their lives" (Roos et al., 2016, p. 2). It has been described that a sense of control contributes to enhancing a person's dignity (Guo and Jacelon, 2014), and perceived loss of control is a risk factor for losing dignity (Monforte et al., 2018). Consequently, empowerment is an important outcome to study when caring for persons with palliative care needs. Relatives and healthcare professionals have responded about the importance of "empowering" patients (McClement et al., 2007; Johnston et al., 2012; Montross et al., 2013), while persons receiving dignity-conserving care have reported having gained "new insights" (Hall et al., 2012) and having the "motivation to achieve things" in the time they have left (Hall et al., 2013).

The findings of this review surprisingly do not include distinct outcomes of "communication," although it was studied on an individual item through the SISC ${ }^{\mathrm{S} 10}$. Communication has been highlighted in previous studies (Johnston et al., 2015b; Werkander Harstäde et al., 2017) that have reviewed dignityconserving care actions and have indicated that it is central to this type of care. Further, as poor communication can have a negative effect on a person's dignity (Guo and Jacelon, 2014), this outcome must be considered when evaluating dignity-conserving care. Due to the lack of concrete communication outcomes in this review, an exploration of communication must in the future receive more attention and must be given equal emphasis in care and research. Not evaluating this outcome could jeopardize the delivery of high-quality care, as communication skills are required for dignity-conserving care (Johnston et al., 2017b).

In summary, researchers can use this review for guidance while aiming to evaluate dignity-conserving care. The recommendation is to use outcomes presented within each cluster theme to receive a broad overview of a person's situation.

\section{Limitations}

Integrative reviews play an important role in evidence-based practice for nursing care (Whittemore and Knafl, 2005). This study used an integrative approach to include studies with different designs and methodologies. We do not claim to have included all relevant articles on the subject, but we used four databases and performed a manual search, which provided an extensive base of articles to explore. The search strategy included many doublets, indicating saturation. Trustworthiness was enhanced by using inclusion and exclusion criteria to identify relevant studies, as well as by discussions among all researchers about the criteria. Sometimes articles did not use the term "dignity-conserving care" but instead referred to "an intervention to enhance dignity." These articles were also included as there still are not many dignity-conserving care interventions, and it was thought that they might provide valuable information.

Because our aim was not focused on designs or finding effects, a critical appraisal of articles was not accomplished. There is no agreed standard as to when to perform a critical appraisal of the quality of articles; according to Whittemore and Knafl (2005), the quality appraisal should be done if fulfilling a meaningful purpose. It is most likely that a type 2 error (where real effects cannot be found even though they, in fact, exist) was made in several of the included studies. This proves that more studies with a more robust study design and including more participants are needed if effects are to be identified. For ethical considerations (Holstein et al., 2011), articles only focusing on persons with dementia were excluded, as these persons can be considered as too frail and dignity-conserving care often includes reflective conversations requiring the ability to think clearly and to process dialogues.

Moreover, we found it challenging to assign some of the outcomes to an appropriate theme because outcomes often overlapped. This may be due to the complexity of the palliative care context; and according to Alvesson's (2017) themes in an analysis, cannot always be completely isolated.

\section{Conclusions}

Consideration of relevant outcomes is central to implementing new interventions. It is hoped that this study can be an important source for researchers evaluating dignity-conserving care, inspiring them to use a broad approach of outcomes or outcomes within "Themes regarding Overarching Dignity Issues." Over and above outcomes within "Themes related to Illness-Related Concerns," there is a need to give an equal and enhanced focus to outcomes within cluster themes "Themes related to the Dignity-Conserving Repertoire" and "Themes related to the Social Dignity Inventory" to increase or maintain the dignity of a person with palliative care needs. An increased focus on "Communication outcomes" within dignity-conserving care is highly desirable to help improve the care provided within palliative care today.

Supplementary material. The supplementary material for this article can be found at https://doi.org/10.1017/S1478951520000139 
Acknowledgments. The authors thank the Research School of Successful Ageing at Örebro University, Örebro, Sweden, which funded the research time of the first author Annika Söderman. The authors also thank Professor Eva Benzein for valuable input in planning this review.

Conflict of interest. The authors declare no conflict of interest.

Author Contributions. All authors took part in the study conception, design, drafting of the manuscript, writing, and final editing of the manuscript. The first and last author (A.S. and K.B.) were responsible for most of the data collection, while the first and second author (A.S. and U.Ö.) took main responsibility for the data analysis. All authors were involved in critical revision of the manuscript for important intellectual content.

\section{References}

Studies analyzed for this reviews result are marked with a number, for example [S1]

Akpan A, Roberts C, Bandeen-Roche K, et al. (2018) Standard set of health outcome measures for older persons. BMC Geriatrics 18(1), 36. doi:10.1186/ s12877-017-0701-3

Alvesson M (2017) Interpretation and reflection: philosophy of science and qualitative method, 3rd ed. Lund: Studentlitteratur.

Aoun SM, Breen LJ, O'Connor M, et al. (2012) A public health approach to bereavement support services in palliative care.Australian and New Zealand Journal of Public Health 36(1), 14-16. doi:10.1111/j.1753-6405.2012.00825.x

Aoun SM, Chochinov HM and Kristjanson LJ (2015) Dignity Therapy for people with motor neuron disease and their family caregivers: A feasibility study [S1]. Journal of Palliative Medicine 18(1), 31-37. doi:10.1089/ jpm.2014.0213

Barclay L (2016) In sickness and in dignity: A philosophical account of the meaning of dignity in health care. International Journal of Nursing Studies 61, 136-141. doi:10.1016/j.ijnurstu.2016.06.010

Bauereiß M, Obermeier S, Özünal SE, et al. (2018) Effects of existential interventions on spiritual, psychological, and physical well-being in adult patients with cancer: Systematic review and meta-analysis of randomized controlled trials. Psycho-Oncology 27(11), 2531-2545. https://doi.org/10. 1002/pon. 4829

Bentley B, O'Connor M, Kane R, et al. (2014) Feasibility, acceptability, and potential effectiveness of Dignity Therapy for people with motor neurone disease ${ }^{[S 2]}$. PLoS ONE 9(5). doi:10.1371/journal.pone.0096888

Bernat JK, Helft PR, Wilhelm LR, et al. (2015) Piloting an abbreviated dignity therapy intervention using a legacy-building web portal for adults with terminal cancer: A feasibility and acceptability study ${ }^{[\mathrm{S} 3]}$. Psycho-Oncology 24(12), 1823-1825. doi:10.1002/pon.3790

Bland M (2015) An introduction to medical statistics. Oxford: Oxford University Press.

Brennan F (2017) "To die with dignity": An update on palliative care. Internal Medicine Journal 47(8), 865-871. doi:10.1111/imj.13520

Brodtkorb K, Skisland AV-S, Slettebø Å, et al. (2016) Preserving dignity in end-of-life nursing home care: Some ethical challenges. Nordic Journal of Nursing Research 37(2), 78-84. doi:10.1177/2057158516674836

Byock IR and Merriman MP (1998) Measuring quality of life for patients with terminal illness: The Missoula-VITAS quality of life index. Palliative Medicine 12(4), 231-244.

Chochinov HM (2002) Dignity-conserving care - a new model for palliative care: Helping the patient feel valued. JAMA 287(17), 2253-2260.

Chochinov HM (2007) Dignity and the essence of medicine: The A, B, C, and D of dignity conserving care. BMJ 335(7612), 184-187. doi:10.1136/ bmj.39244.650926.47

Chochinov HM, Hack T, Hassard T, et al. (2005) Dignity therapy: A novel psychotherapeutic intervention for patients near the end of life ${ }^{[\mathrm{S} 4]}$. Journal of Clinical Oncology 23. doi:10.1200/jco.2005.08.391

Chochinov HM, Kristjanson LJ, Hack TF, et al. (2007) Burden to others and the terminally ill. Journal of Pain and Symptom Management 34(5), 463471. doi:10.1016/j.jpainsymman.2006.12.012

Chochinov HM, Hassard T, McClement S, et al. (2008) The Patient Dignity Inventory: A novel way of measuring dignity-related distress in palliative care. Journal of Pain and Symptom Management 36(6), 559-571. http:// dx.doi.org/10.1016/j.jpainsymman.2007.12.018

Chochinov HM, Kristjanson LJ, Breitbart W, et al. (2011) Effect of dignity therapy on distress and end-of-life experience in terminally ill patients: A randomised controlled trial ${ }^{[S 5]}$. Lancet Oncology 12(8), 753-762. doi:10.1016/S1470-2045(11)70153-X

Chochinov HM, McClement S, Hack T, et al. (2015) Eliciting personhood within clinical practice: Effects on patients, families, and health care providers ${ }^{[S 20]}$. Journal of Pain and Symptom Management 49. doi:10.1016/ j.jpainsymman.2014.11.291

Chochinov HM, Johnston W, McClement SE, et al. (2016) Dignity and distress towards the end of life across four non-cancer populations. PLoS ONE 11(1).doi:10.1371/journal.pone. 0147607

Cohen SR, Sawatzky R, Russell LB, et al. (2017) Measuring the quality of life of people at the end of life: The McGill Quality of Life Questionnaire-Revised. Palliative Medicine 31(2), 120-129. doi:10.1177/0269216316659603

Cross LA (2019) Compassion fatigue in palliative care nursing: A concept analysis. Journal of Hospice and Palliative Nursing 21(1), 21-28. https:/ doi.org/10.1097/NJH.0000000000000477

Da Rocha Rodrigues MG, Pautex S and Shaha M (2016) Revie $\oplus$ : The influence of a life review intervention including a positive, patient-centered approach towards enhancing the personal dignity of patients with advanced cancer - a study protocol for a feasibility study using a mixed method investigation ${ }^{[\mathrm{S} 21]}$. Pilot and Feasibility Studies 2(1), 63. doi:10.1186/s40814-016-0101-z

Department of Health (2010) Equity and excellence: Liberating the NHS. London: NHS.

Donato SCT, Matuoka JY, Yamashita CC, et al. (2016) Effects of dignity therapy on terminally ill patients: A systematic review. Revista da Escola de Enfermagem da USP 50(6), 1011-1021. http://dx.doi.org/10.1590/ S0080-623420160000700019

Evans CJ, Benalia H, Preston NJ, et al. (2013) The selection and use of outcome measures in palliative and end-of-life care research: The MORECare International Consensus Workshop. Journal of Pain and Symptom Management 46(6), 925-937. doi:10.1016/j.jpainsymman.2013.01.010

Fitchett G, Emanuel L, Handzo G, et al. (2015) Care of the human spirit and the role of dignity therapy: A systematic review of dignity therapy research. BMC Palliative Care 14(8), 1-12. doi:10.1186/s12904-015-0007-1

Gallagher A, Li S, Wainwright P, et al. (2008) Dignity in the care of older people - a review of the theoretical and empirical literature. $B M C$ Nursing 7(11), 1-12. doi.org/10.1186/1472-6955-7-11

Grassi L, Mezzich JE, Nanni MG, et al. (2017) A person-centred approach in medicine to reduce the psychosocial and existential burden of chronic and life-threatening medical illness. International Review of Psychiatry 29(5), 377-388. doi:10.1080/09540261.2017.1294558

Grossman CH, Brooker J, Michael N, et al. (2018) Death anxiety interventions in patients with advanced cancer: A systematic review. Palliative Medicine 32(1), 172-184. https://doi.org/10.1177/0269216317722123

Guo G and Jacelon CS (2014) An integrative review of dignity in end-of-life care. Palliative Medicine 28. doi:10.1177/0269216314528399

Hack TF, Chochinov HM, Hassard T, et al. (2004) Defining dignity in terminally ill cancer patients: A factor-analytic approach. Psycho-oncology 13. doi:10.1002/pon.786

Hall S, Chochinov H, Harding R, et al. (2009a) A phase II randomised controlled trial assessing the feasibility, acceptability and potential effectiveness of dignity therapy for older people in care homes: Study protocol ${ }^{[\mathrm{S} 6]}$. BMC Geriatrics 9, 9. doi:10.1186/1471-2318-9-9

Hall S, Edmonds P, Harding R, et al. (2009b) Assessing the feasibility, acceptability and potential effectiveness of Dignity Therapy for people with advanced cancer referred to a hospital-based palliative care team: Study protocol $^{[\mathrm{S} 7]}$. BMC Palliative Care 8(5), 1-8. doi:10.1186/1472-684x-8-5

Hall S, Goddard C, Opio D, et al. (2011a) Feasibility, acceptability and potential effectiveness of Dignity Therapy for older people in care homes: A phase II randomized controlled trial of a brief palliative care psychotherapy ${ }^{[\mathrm{S} 8]}$. Palliative Medicine 26(5), 703-712. doi:10.1177/0269216311418145

Hall S, Goddard C, Opio D, et al. (2011b) A novel approach to enhancing hope in patients with advanced cancer: A randomised phase II trial of dignity therapy ${ }^{[\mathrm{S} 9]}$. BMJ Supportive \& Palliative Care 1(3), 315-321. doi:10.1136/bmjspcare-2011-000054 
Hall S, Goddard C, Speck PW, et al. (2012) 'It makes me feel that I'm still relevant': A qualitative study of the views of nursing home residents on dignity therapy and taking part in a phase II randomised controlled trial of a palliative care psychotherapy. Palliative Medicine 27(4), 358-366. doi: $10.1177 / 0269216312449272$

Hall S, Goddard C, Speck PW, et al. (2013) It makes you feel that somebody is out there caring: A qualitative study of intervention and control participants' perceptions of the benefits of taking part in an evaluation of dignity therapy for people with advanced cancer. Journal of Pain and Symptom Management 45(4), 712-725. doi:10.1016/j.jpainsymman.2012.03.009

Hemati Z, Ashouri E, AllahBakhshian M, et al. (2016) Dying with dignity: A concept analysis. Journal of Clinical Nursing 25(9-10), 1218-1228. doi:10.1111/jocn.13143

Hesse M, Forstmeier S, Mochamat M, et al. (2019) A review of biographical work in palliative care. Indian Journal of Palliative Care 25(3), 445-454. doi:10.4103/IJPC.IJPC 16 19

Ho AHY, Chan CLW and Leung PPY (2014) Dignity and quality of life in community palliative care. In Fong K and Tong KW (eds.), Community Care in Hong Kong: Current Practices, Practice-research Studies and Future Directions. Hong Kong: City University of Hong Kong Press.

Ho AHY, Dai AAN, Lam S-h, et al. (2016) Development and pilot evaluation of a novel dignity-conserving end-of-life (EoL) care model for nursing homes in Chinese societies ${ }^{[\mathrm{S} 22]}$. The Gerontologist 56(3), 578-589. doi:10.1093/geront/gnv037

Ho AHY, Car J, Ho M-HR, et al. (2017) A novel Family Dignity Intervention (FDI) for enhancing and informing holistic palliative care in Asia: Study protocol for a randomized controlled trial ${ }^{[S 23]}$. Trials 18(587), 1-12. doi:10.1186/s13063-017-2325-5

Höglander J, Eklund JH, Eide H, et al. (2017) Registered nurses' and nurse assistants' responses to older persons' expressions of emotional needs in home care. Journal of Advanced Nursing 73(12), 2923-2932. doi:10.1111/ jan.13356

Holstein M, Parks JA and Waymack MH (2011) Ethics, aging, and society: The critical turn. New York: Springer.

Houmann LJ, Chochinov HM, Kristjanson LJ, et al. (2014) A prospective evaluation of dignity therapy in advanced cancer patients admitted to palliative care [s10]. Palliative Medicine 28(5), 448-458. doi:10.1177/ 0269216313514883

Hulbert-Williams NJ, Beatty L and Dhillon HM (2018) Psychological support for patients with cancer: Evidence review and suggestions for future directions. Supportive and Palliative Care 12(3), 276-292. doi:10.1097/ SPC. 0000000000000360

Jefford M, Stockler MR and Tattersall MHN (2003) Outcomes research: What is it and why does it matter? Internal Medicine Journal 33(3), 110-118.

Johns SA (2013) Translating dignity therapy into practice: Effects and lessons learned ${ }^{[S 11]}$. Omega: Journal of Death and Dying 67(1-2), 135-145. doi:10.2190/OM.67.1-2.p

Johnston B, Östlund U and Brown H (2012) Evaluation of the Dignity Care Pathway for community nurses caring for people at the end of life. International Journal of Palliative Nursing 18(10), 483-489.

Johnston B, Gaffney M, Pringle J, et al. (2015a) The person behind the patient: A feasibility study using the Patient Dignity Question for patients with palliative care needs in hospital ${ }^{[\mathrm{S} 24]}$. International Journal of Palliative Nursing 21(2), 71-77. doi:10.12968/ijpn.2015.21.2.71

Johnston B, Larkin P, Connolly M, et al. (2015b) Dignity-conserving care in palliative care settings: An integrative review. Journal of Clinical Nursing 24(13-14), 1743-1772.

Johnston B, Pringle J, Gaffney M, et al. (2015c) The dignified approach to care: A pilot study using the Patient Dignity Question as an intervention to enhance dignity and person-centered care for people with palliative care needs in the acute hospital setting ${ }^{[\mathrm{S} 25]}$. BMC Palliative Care 14(9), 1-14. doi:10.1186/s12904-015-0013-3

Johnston B, Flemming K, Narayanasamy MJ, et al. (2017a) Patient reported outcome measures for measuring dignity in palliative and end of life care: A scoping review. BMC Health Services Research 17(574), 1-15. doi:10.1186/ s12913-017-2450-6

Johnston B, Papadopoulou C, Östlund U, et al. (2017b) What's dignity got to do with it? Patient experience of the Dignity Care Intervention:
A qualitative evaluation study. SAGE Open Nursing 3. doi:10.1177/ 2377960817699839

Julião M, Barbosa A, Oliveira F, et al. (2013) Efficacy of dignity therapy for depression and anxiety in terminally ill patients: Early results of a randomized controlled trial ${ }^{\left[{ }^{[12]}\right.}$. Palliative \& Supportive Care 11(6), 481-489. doi:10.1017/S1478951512000892

Julião M, Oliveira F, Nunes B, et al. (2014) Efficacy of dignity therapy on depression and anxiety in Portuguese terminally ill patients: A phase II randomized controlled trial ${ }^{[\mathrm{S} 13]}$. Journal of Palliative Medicine 17(6), 688-695. doi:10.1089/jpm.2013.0567

Julião M, Oliveira F, Nunes B, et al. (2017) Effect of dignity therapy on end-of-life psychological distress in terminally ill Portuguese patients: A randomized controlled trial ${ }^{[\mathrm{S} 14]}$. Palliative and Supportive Care 15(6), 628-637. doi:10.1017/S1478951516001140

Kennedy G (2016) The importance of patient dignity in care at the end of life. The Ulster Medical Journal 85(1), 45-48.

Lau RWL and Cheng S-T (2011) Gratitude lessens death anxiety. European Journal of Ageing 8(3), 169-175. doi:10.1007/s10433-011-0195-3

Lendon JP, Ahluwalia SC, Walling AM, et al. (2015) Measuring experience with end-of-life care: A systematic literature review. Journal of Pain and Symptom Management 49(5), 904-915. doi:10.1016/j.jpainsymman.2014.10.018

Lindskog M, Tavelin B and Lundström S (2015) Old age as risk indicator for poor end-of-life care quality - a population-based study of cancer deaths from the Swedish Register of Palliative Care. European Journal of Cancer 51(10), 1331-1339. doi:10.1016/j.ejca.2015.04.001

Lucas PJ, Baird J, Arai L, et al. (2007) Worked examples of alternative methods for the synthesis of qualitative and quantitative research in systematic reviews. BMC Medical Research Methodology 7(4), 1-7. doi:10.1186/1471-2288-7-4

Martínez M, Arantzamendi M, Belar A, et al. (2017) 'Dignity therapy', a promising intervention in palliative care: A comprehensive systematic literature review. Palliative Medicine 31(6), 492-509. doi.org/10.1177/0269216316665562

McCance T, McCormack B and Dewing J (2011) An exploration of personcentredness in practice. Online Journal of Issues in Nursing 16(2), 1-1. doi:10.3912/OJIN.Vol16No02Man01

McClement S, Chochinov HM, Hack T, et al. (2007) Dignity therapy: Family member perspectives. Journal of Palliative Medicine 10(5), 1076-1082. doi:10.1089/jpm.2007.0002

McIlfatrick S, Connolly M, Collins R, et al. (2017) Evaluating a dignity care intervention for palliative care in the community setting: Community nurses' perspectives. Journal of Clinical Nursing 26(23-24), 4300-4312. doi:10.1111/jocn.13757

Moher D, Liberati A, Tetzlaff J, Altman DG, The PRISMA Group (2009) Preferred Reporting Items for Systematic Reviews and MetaAnalyses: The PRISMA Statement. PLoS Med 6(7), e1000097. https://doi.org/10.1371/ journal.pmed 1000097

Monforte RC, Crespo I, Rodríguez PA, et al. (2018) The role of perceived dignity and control in the wish to hasten death among advanced cancer patients: A mediation model. Psycho-Oncology 27(12), 2840-2846. https:// doi.org/10.1002/pon.4900

Montross LP, Meier EA, De Cervantes-Monteith K, et al. (2013) Hospice staff perspectives on Dignity Therapy. Journal of Palliative Medicine 16 (9), 1118-1120. doi:10.1089/jpm.2013.0030

Montross-Thomas LP, Irwin SA, Meier EA, et al. (2015) Enhancing legacy in palliative care: Study protocol for a randomized controlled trial of Dignity Therapy focused on positive outcomes ${ }^{[\mathrm{S15}]}$. BMC Palliative Care 14(44), 1-8. doi:10.1186/s12904-015-0041-z

Passik SD, Kirsh KL, Leibee S, et al. (2004) A feasibility study of dignity psychotherapy delivered via telemedicine ${ }^{[\mathrm{S16}]}$. Palliative and Supportive Care 2 (2), 149-155.

Roikjær SG, Missel M, Bergenholtz HM, et al. (2019) The use of personal narratives in hospital-based palliative care interventions: An integrative literature review. Palliative Medicine. https://doi.org/10.1177/ 2F0269216319866651

Roos C, Silén M, Skytt B, et al. (2016) An intervention targeting fundamental values among caregivers at residential facilities: Effects of a clusterrandomized controlled trial on residents' self-reported empowerment, person-centered climate and life satisfaction ${ }^{[526]}$. BMC Geriatrics 16 (130), 1-16. doi:10.1186/s12877-016-0306-2 
Rudilla D, Galiana L, Oliver A, et al. (2016) Comparing counseling and dignity therapies in home care patients: A pilot study ${ }^{[S 17]}$. Palliative and Supportive Care 14(4), 321-329. doi:10.1017/s1478951515001182

Scarton L, Oh S, Sylvera A, et al. (2018) Dignity impact as a primary outcome measure for Dignity Therapy ${ }^{[\mathrm{S} 18]}$. American Journal of Hospice and Palliative Medicine 35(11), 1417-1420. doi:10.1177/1049909118777987

Selman L, Siegert R, Harding R, et al. (2011) A psychometric evaluation of measures of spirituality validated in culturally diverse palliative care populations. Journal of Pain and Symptom Management 42(4), 604-622. https:// doi.org/10.1016/j.jpainsymman.2011.01.015

Sinclair S, Beamer K, Hack TF, et al. (2017) Sympathy, empathy, and compassion: A grounded theory study of palliative care patients' understandings, experiences, and preferences. Palliative Medicine 31(5), 437-447. https://doi.org/10.1177/0269216316663499

Teo I, Krishnan A and Lee GL (2018) Psychosocial interventions for advanced cancer patients: A systematic review. Psycho-Oncology 28(7), 1394-1407. https://doi.org/10.1002/pon.5103

van Gennip IE, Pasman HRW, Oosterveld-Vlug MG, et al. (2015) Dynamics in the sense of dignity over the course of illness: A longitudinal study into the perspectives of seriously ill patients. International Journal of Nursing Studies 52(11), 1694-1704. doi:10.1016/j.ijnurstu.2015.06.010

Vergo MT, Nimeiri H, Mulcahy M, et al. (2014) A feasibility study of dignity therapy in patients with stage IV colorectal cancer actively receiving secondline chemotherapy ${ }^{[\mathrm{S} 19]}$. Journal of Community \& Supportive Oncology 12 (12), 446-453. doi:10.12788/jcso.0096 von Blanckenburg P and Leppin N (2018) Psychological interventions in palliative care. Psychiatry 31(5), 389-395. doi:10.1097/YCO.0000000000000441

Warth M, Kessler J, Koehler F, et al. (2019) Brief psychosocial interventions improve quality of life of patients receiving palliative care: A systematic review and meta-analysis. Palliative Medicine 33(3), 332-345. doi:10.1177/0269216318818011

Werkander Harstäde C, Blomberg K, Benzein E, et al. (2017) Dignity-conserving care actions in palliative care: An integrative review of Swedish research. Scandinavian Journal of Caring Sciences 32(1), 8-23. doi.org/10.1111/scs.12433

Whittemore R and Knafl K (2005) The integrative review: Updated methodology. Journal of Advanced Nursing 52(5), 546-553. doi:10.1111/ j.1365-2648.2005.03621.x

World Health Organization (2018). Integrating palliative care and symptom relief into primary health care: A WHO guide for planners, implementers and managers. World Health Organization. Retrieved from: http://www. who.int/iris/handle/10665/274559

World Health Organization/Worldwide Palliative Care Alliance (2014). Global Atlas of Palliative Care at the End of Life. London: Worldwide Palliative Care Alliance. Retrieved from: https:/www.who.int/nmh/ Global_Atlas_of_Palliative_Care.pdf

Xiao J, Chow KM, Liu Y, et al. (2019) Effects of dignity therapy on dignity, psychological well-being, and quality of life among palliative care cancer patients: A systematic review and meta-analysis. Psycho-Oncology 28 1791-1802. https://doi.org/10.1002/pon.5162 